\title{
ARTICLE
}

\section{THE DEATH OF FIDUCIARY DUTY IN CLOSE CORPORATIONS}

\author{
LAWRENCE E. Mrtchell $\dagger$
}

The internal structure of the corporation produces relationships of power and dependency. As a result, the law of corporations historically has attempted to provide a principled and coherent set of regulations to ensure that those who hold power are accountable to those who are dependent upon its fair exercise. The corporation is a human enterprise, subject to human failings, and the goal of the law has been to prevent, correct, or rectify those failings when necessary.

The bulk of these adjustive mechanisms come under the general heading of fiduciary duty. ${ }^{1}$ It is my thesis that courts, aided in part by legislatures, ${ }^{2}$ increasingly have moved away from applying broad

$\dagger$ Associate Professor, Albany Law School of Union University. B.A. 1978, Williams College; J.D. 1981, Columbia University. I would like to thank Steven Burton, Robert J. Tymann and Hether Macfarlane for their helpful comments on an earlier draft of this Article. I would also like to thank my research assistant, Laura Shannon, whose long days in the library substantially assisted me in preparing this Article.

1 For studies exploring the concept of fiduciary duty, see 2A A. ScotT \& W. Fratcher, The LaW of Trusts $\S \S 170-170.25$ (4th ed. 1987); J.C. Shepherd, The LAw of Fiduciaries (1981); Anderson, Conflicts of Interest: Efficiency, Faimess and Corporate Structure, 25 UCLA L. REv. 738 (1978); Brudney, Corporate Governance, Agency Costs, and the Rhetoric of Contract, 85 CoLum. L. REv. 1403 (1985) [hereinafter Brudney, Corporate Governance]; Brudney, Fiduciary Ideology in Transactions Affecting Corporate Control, 65 Mich. L. REv. 259 (1966) [hereinafter Brudney, Fiduciary Ideology]; Clark, Agency Costs Versus Fiduciary Duties, in Principals and Agents: The STructure of Business 55 (J. Pratt \& R. Zeckhauser eds. 1985); Davis, Judicial Review of Fiduciary Decisionmaking-Some Theoretical Perspectives, 80 Nw. U.L. REv. 1 (1985); DeMott, Beyond Metaphor: An Analysis of Fiduciary Obligation, 1988 Duke L.J. 879; Frankel, Fiduciary Law, 71 CaLif. L. REv. 795 (1983); Jacobson, The Private Use of Public Authority: Sovereignty and Associations in the Common Law, 29 Buffalo L. Rev. 599 (1980); Phillips, Managerial Misuse of Property: The Synthesizing Thread in Corporate Doctrine, 32 RuTGERs L. REv. 184 (1979); Ruder, Duty of Loyally-A Law Professor's Status Report, 40 Bus. Law. 1383 (1985); Scott, The Fiduciary Principle, 37 Calif. L. REv. 539 (1949); Sealy, Fiduciary Relationships, 1962 CAMBRIDGE L.J. 69; Shepherd, Towards a Unified Concept of Fiduciary Relationships, 97 LAw Q. REv. 51 (1981); Weinrib, The Fiduciary Obligation, 25 U. TORONTO L.J. I (1975).

2 Legislative aid has come, for instance, in the form of statutes providing 
prophylactic fiduciary principles to prevent or resolve intra-corporate conflicts. ${ }^{3}$ In the context of close corporations, ${ }^{4}$ courts have quietly abandoned those principles and replaced them with remedial approaches which focus on the putative fiduciary's wrongful conduct. The result is a subtle but significant change in the law's normative aspirations from those on which classic fiduciary principles are based.

The classic statement of the fiduciary principle is that, within the scope of the relationship, the fiduciary is to act in a disinterested manner in the beneficiary's best interests. ${ }^{5}$ Conduct deviating from that standard results in liability, regardless of the fiduciary's motive or intent. ${ }^{6}$ The problem burdening fiduciary analysis in the law of close corporations is that those considered fiduciaries in close corporations are not, in fact, disinterested. They generally own significant, if not controlling, amounts of the corporation's stock. ${ }^{7}$ Thus, the fiduciary shares with the beneficiary a legitimate claim to the "trust" property over which she has exclusive control.

Faced with this shared interest, the nature of corporate governance, including majority rule and the substantial latitude accorded directors and officers in managing the corporation, ${ }^{8}$ and the right of

remedies for corporate shareholders complaining of oppressive conduct by the majority. See infra note 19.

3 See infra notes $47-213$ and accompanying text.

4 This Article defines close corporations as those having a relatively small number of shareholders. Shareholders in close corporations share three characteristics: They tend to have a substantial portion of their personal wealth invested in the corporation, to be intimately involved in its management, and to restrict membership in the corporation. See Mitchell, Close Corporations Reconsidered, 63 TuL. L. Rev, 1143, 1151 (1989). With regard to an analysis of fiduciary duty in close corporations, the most important characteristic is the substantial involvement of shareholders in management. Cf. Anderson, supra note 1, at 759 (noting that the "separation of ownership and control is the source of legal conflicts of interest").

5 See, e.g., RESTATEMENT (SECOND) OF Trusts $\$ 170$ (1959) (noting that the duty of loyalty requires a fiduciary to act solely in the interest of the beneficiary); $2 \mathrm{~A} \mathrm{~A}$. Scotr \& W. FRATCHER, supra note $1, \S 170$, at 311 (stating that a fiduciary is not permitted to place herself in a position where it would benefit her to violate her duty to the beneficiary).

6 See G. Bogert \& G. Boger'r, Handbook of the Law of Trusts $\S 95$, at 345 (5th ed. 1973) (holding that "[w]hether the trustee acted in good faith and with honest intention is not relevant . . ."); see also AC Acquisitions Corp. v. Anderson, Clayton \& Co., 519 A.2d 103, 115 (Del. 1986) ("[M]ere good faith will not preclude a finding of a breach of the duty of loyalty .... [T] he transaction can only be sustained if it is objectively or intrinsically fair . . ..").

7 See Mitchell, supra note 4, at 1144-45 (noting that the separation of ownership and control in a close corporation is minimal if it exists at all).

8 See, e.g., Del. Code ANn. tit. 8, § 141 (a) (1983) (granting broad managerial powers to the board of directors); ALI Principles of Corporate Governance $\$ 3.02$ 
directors and officers, as shareholders, to consider their own selfinterest, ${ }^{9}$ courts largely have abandoned any attempt to distinguish conduct undertaken in the best interests of the corporation and its shareholders from that undertaken for the benefit of the controlling interests. Problems concerning the adjudication of fiduciary liability are compounded by the fact-specific nature of fiduciary analysis, which diminishes predictability and consistency. Courts seeking greater certainty and consistency have begun to use tests requiring less subtle evaluations to determine when a fiduciary duty has been breached.

The new tests, while often couched in fiduciary language, require proof of some form of affirmative bad faith or intentional misconduct by the fiduciary. ${ }^{10}$ By shifting the inquiry from the beneficiary's best interests to a more limited focus on the fiduciary's malfeasance, these tests provide greater latitude than do traditional fiduciary principles for corporate fiduciaries to pursue their own interests, and diminish the power of the law to inspire and enforce high standards of business ethics. They also change the function of corporate fiduciary principles from a broad prophylactic measure to a tool to remedy substantial misconduct. The important question these observations raise is whether the new modes of analysis are superior to fiduciary principles in guiding the conduct of corporate actors and resolving intra-corporate disputes. The answer ultimately turns on one's view of the desirable level of ethical conduct in close corporations and the acceptability of the social vision underlying fiduciary duty. ${ }^{11}$

(Tent. Draft No. 2 1984) (recommending broad powers for corporate board of directors); REv. MODEL BusINEsS CoRP. AcT § 8.01(b) (1984) (stating that subject to any limitations in the articles of incorporation, all,corporate powers shall be exercisable by or under the authority of the board of directors); H. HENN \& J. AleXander, Laws of Corporations and OTHER Business ENTERPrises $\$ 242$ (3d ed. 1983) (describing the "business judgment" rule which substantially insulates management from liability for its actions).

9 See, e.g., Hetherington, Defining the Scope of Controlling Shareholders' Fiduciary Responsibilities, 22 Wake Foresr L. REv. 9, 12 (1987) [hereinafter Hetherington, Defining the Scope] (noting that while corporate officials must act in accordance with fiduciary principles, shareholders have traditionally owed no fiduciary obligations to each other and have been free to act solely in their own self-interest).

10 Cf. Hetherington \& Dooley, Illiquidity and Exploitation: A Proposed Statutory Solution to the Remaining Close Corporation Problem, 63 VA. L. REv. 1, 11 (1977) (discussing judicial dissolution statutes and noting that they require "[p]roof of fraud, illegality, waste, or misapplication of assets [that is] similar to that necessary to prevail in a damage suit for breach of the fiduciary duties of loyalty or due care").

11 Legal analysis alone cannot provide the answer to this question. Legal analysis can, however, identify the question, examine the current competing 
Fiduciary analysis presents a singular problem in corporate law generally. The self-interest of officers and directors in the corporation and its assets, ${ }^{12}$ and the wide discretion granted them in the performance of their jobs, ${ }^{13}$ have led courts to abandon any attempt

proposals, and suggest solutions. Cf. Branson, Assault on Another Citadel: Attempts to Curtail the Fiduciary Standard of Loyalty Applicable to Corporate Directors, 57 FORDHAM L. Rev. 375, 402 (1988) (criticizing the proposals of the American Law Institute's Corporate Governance Project and the Model Business Corporation Act as being guided by corporate, rather than public interest).

12 For instance, Chief Judge Seitz, a former Delaware chancellor, wrote in the public corporation context:

It is frequently said that directors are fiduciaries. Although this statement is true in some senses, it is also obvious that if directors were held to the same standard as ordinary fiduciaries the corporation could not conduct business. For example, an ordinary fiduciary may not have the slightest conflict of interest in any transaction he undertakes on behalf of the trust. Yet by the very nature of corporate life a director has a certain amount of self-interest in everything he does. The very fact that the director wants to enhance corporate profits is in part attributable to his desire to keep shareholders satisfied so that they will not oust him.

Johnson v. Trueblood, 629 F.2d \&.87, 292 (3d Cir. 1980), cert. denied, 450 U.S. 999 (1981). The self-interest of corporate management often presents itself as a direct conflict between the financial interests of the corporation and the manager. See, e.g., Anderson, supra note 1 , at 758 (" $[T]$ he economic interests of fiduciaries are frequently substantially affected by the discretionary decisions they make on behalf of others, since ... the magnitude of their own compensation for their services often depends to an unusual degree on decisions which they themselves make."); Davis, supra note 1, at 65 (noting the inevitability of conflicts of interest in the areas of management compensation and responses to takeover bids). But see Fama, Agency Problems and the Theory of the Firm, 83 J. PoL. Econ. 288, 295 (1980) (arguing that "the discipline imposed by managerial labor markets can resolve potential incentive problems associated with the separation of security ownership and control of the firm").

13 See supra note 8. By granting managers broad discretion, the business judgment rule protects management in its risk taking function. See, e.g., Joy v. North, 692 F.2d 880, 886 (2d Cir. 1982) (asserting that a purpose of the business judgment rule is to guarantee against overly cautious corporate decisions), cert. denied, 460 U.S. 1057 (1983). As an outgrowth of the directors' duty of care, the business judgment rule is sometimes thought not to embody fiduciary principles. See, e.g., J.C. SHEPHERD, supra note 1 , at 49 (asserting that "the duty of care has absolutely no necessary connection with fiduciary relationships"); DeMott, supra note 1, at 915 (noting that the duty of care is not fiduciary in character); Ruder, supra note 1, at 1385 (concluding that the business judgment rule is part of the general duty of care and should not be treated in an article discussing the duty of loyalty). But see Jacobson, supra note 1 , at 622-23 iasserting that the fiduciary obligation includes a duty to conduct the affairs of the beneficiary as a reasonably prudent person would conduct her own affairs). The risk-taking function is inevitably intertwined with fiduciary doctrine given the impossibility in any given situation of neatly categorizing directors' conduct as falling under either the duty of care or the duty of loyalty. $C f$. Comment, Of Synergies of Evidence and Section 402(b)(1): Hanson Trust, Revlon, Van Gorkom, and the Imminent Demise of tire First Wave of Corporate Director Liability Statutes, 52 
to hold corporate fiduciaries to the same high standard of conduct required of other fiduciaries. ${ }^{14}$ The judicial and legislative response has been the development of both procedural and substantive rules that permit the sanitization of almost all self-interested transactions,

ALB. L. Rev. 559, 589-94 (1988) (arguing that recent cases finding directors liable have commingled duty of care and duty of loyalty analyses).

14 See Brudney, The Independent Director-Heavenly City or Potemkin Village?, 95 HaRv. L. Rev. 597, 607-08 (1982); Frankel, supra note 1, at 805-07; Hetherington \& Dooley, supra note 10, at 39; Ruder, supra note 1, at 1385; Scott, supra note 1, at 555 n.30.

Determining the salary levels of inside directors is an example of inherently selfinterested corporate fiduciary conduct and the consequent problems courts have in analyzing its propriety. See, e.g., Rogers v. Hill, 289 U.S. 582, 591 (1933) (stating that corporate by-laws may not allow salaries so large as to amount to spoilage or waste of corporate property); Davis, supra note 1, at 84 (reasoning that because such transactions are never at arm's length, the court cannot find a set of terms that independent parties would have reached and must rely on abstract notions of fairness); Ruder, supra note $I$ at 1392-93 (noting that although executive compensation is subject to review by the courts, it will not be deemed a breach of duty unless it amounts to "spoliation or waste"). But see Fama, supra note 12, at 296304 (arguing that an efficient managerial labor market effectively regulates the setting of management wages).

Cases involving the implementation of defensive measures against hostile takeovers provide other examples of inherently self-interested conduct. See, e.g., Panter v. Marshall Field \& Co., 646 F.2d 271, 297 (7th Cir.) (refusing to impose liability for both a defensive acquisition in the face of a hostile takeover bid and for filing an antitrust suit against the hostile bidder), cert. denied, 454 U.S. 1092 (1981); Johnson, 629 F.2d at 292-93 (affirming that under Delaware law a decision to adopt defensive measures is protected by the business judgment rule unless solely or primarily motivated by a desire to maintain control); Moran v. Household Int'l Inc., 500 A.2d 1346, 1357 (Del. 1985) (refusing to impose liability for a poison pill plan); Davis, supra note 1 , at 80-82 (noting that, despite the criticism of the commentators, most courts, under the business judgment rule, have protected directors' decisions to take defensive measures); Ruder, supra note 1, at 1394 (noting that defensive measures present a "mixed motive" problem that is difficult for the trier of fact to resolve).

Opposing positions with regard to the appropriate scrutiny of directors' actions in hostile takeovers are illustrated by the opinions of Judges Pell and Cudahy in Panter. Compare Panter, 646 F.2d at 296-97 (holding that in the absence of proof by the plaintiff of impermissible motive, the business judgment rule protects directorial action in the face of a hostile takeover) with id. at 299-301 (Cudahy, J., concurring in part and dissenting in part) (arguing that when fighting hostile takeovers, directors have a clear interest in self-preservation, and that the business judgment rule places the burden of proof on the director to establish that the transaction was fair to the corporation).

The pervasive psychological bias of directors towards management noted by Cox and Munsinger suggests that all directorial conduct, to a greater or lesser extent, may be self-interested. See Cox \& Munsinger, Bias in the Boardroom: Psychological Foundations and Legal Implications of Corporate Cohesion, 48 LAW \& ConTEMP. ProBs. 83, 85-108 (1985). For a critical analysis of this and similar studies, see Davis, supra note 1, at 68-74. The problem of proving directorial self-interest lies at the heart of Professor Shepherd's theory. See J.C. Shepherd, supra note 1. 
although some extreme forms of selfish conduct flatly are prohibited. ${ }^{15}$ These rules have stripped fiduciary principles of their traditional preventive function and normative content.

Although corporate law permits most self-dealing upon compliance with specific rules, with. respect to close corporations the courts speak of fiduciary duty in a more general sense. Judges continue to infuse fiduciary analysis in close corporation law with the ringing rhetoric of then-Judge Cardozo's opinion in Meinhard $v$. Salmon. ${ }^{16}$ But it is increasingly rare that courts apply the principles underlying that rhetoric. Rather, fiduciary analysis in close corporation law has moved in three stages from the strict application of standards of loyalty, to judicial balancing of the legitimate interests of controlling shareholders with those of the minority, to the contemporary treatment of breach of fiduciary duty as intentional wrongful conduct. ${ }^{17}$ The common law tort of freeze-out ${ }^{18}$ and the statutory remedy for

15 See Brudney, Fiduciary Ideology, supra note 1, at 299, 300 (concluding that functional concerns limit the use of fiduciary ideology in corporate law); Davis, supra note 1 , at 24, 51, 84 (noting that interested director transactions are subject to a fairness standard); Ruder, supra note 1, at 1389-1402 (noting that extreme forms of self-dealing, including abuse of parent-subsidiary relations, transactions unfair to minority shareholders, excessive compensation, obstruction of takeovers primarily for the purpose of entrenchment, sale of corporate office, insider trading, and usurpation of corporate opportunities, are not permitted); see also Chiles v. Robertson, 94 Or. App. 604, 625-39, 767 P.2d 903, 915-23 (finding a violation of fiduciary duty on the part of directors of a parent corporation when they caused subsidiaries to approve a tranisaction without considering the subsidiaries' independent interests in the transaction), modified on other grounds, 96 Or. App. 658, 774 P.2d 500, review denied, 308 Or. 592, 784 P.2d 1099 (1989).

The paradigmatic procedural rules are those like Dez. Code ANN. tit. 8, § 144 (1983), which permit interested director transactions upon approval of a majority of disinterested directors or shareholders. The paradigmatic substantive rule is the fairness test which is applied in various situations, for example, in the context of a parent-subsidiary merger. See, e.g., Alpert v. 28 Williams St. Corp., 63 N.Y.2d 557, 569-71, 473 N.E.2d 19, 26-27, 483 N.Y.S.2d 667, 674-75 (1984) (stating that fairness, in the context of a freeze-out merger, includes fair price and fair dealing); Weinberger v. UOP, Inc., 457 A.2d 701, 711 (Del. 1983) (stating that when directors of a Delaware corporation are on both sides of a transaction, that transaction must satisfy the fairness test which consists of fair dealing and fair price). The fairness test may also be invoked when a parent engages in self-dealing with a subsidiary. See Sinclair Oil Corp. v. Levien, 280 A.2d 717, 720 (Del. 1971).

16249 N.Y. 458, 164 N.E. 545 (1928). The omnipresence of Meinhard in discussions of this topic has been noted. See, e.g., DeMott, supra note 1, at $891 \mathrm{n} .56$ (observing the prevalence of Meinhard's moral obligation language in case law and commentaries on corporate fiduciary duty); Ruder, supra note 1, at 1386 (stating that Meinhard continues to quoted by ccurts imposing corporate fiduciary obligations).

17 As I will show later, in Massachusetts, the entire progression occurred in the span of only eleven years. See infra notes $98-168$ and accompanying text.

18 See Sugarman v. Sugarman, 797 F.2d 3, 14 (1st Cir. 1986). 
oppression $^{19}$ are the principal guises in which this last stage has occurred and are increasingly replacing fiduciary analysis as the method of resolving internal close corporation disputes. ${ }^{20}$

In this Article, I will attempt to demonstrate that in the course of abandoning fiduciary principles for analyses requiring less subtle evaluations, courts implicitly have rejected the assumptions on which those principles were based as well as the vision of corporate ethics embodied in those principles. Instead of encouraging high levels of internal corporate conduct, courts now seem content to rely on "the morals of the market place."21 The consequence is a significant dilution of fiduciary duty as an aspirational precept to guide the conduct

19 In this Article, I use the term "oppression statute" generically to denote those statutes, adopted in approximately three-quarters of the states, that provide remedies to shareholders who seek some form of judicial relief from the actions of controlling shareholders. The typical statute provides relief upon a showing of fraudulent, illegal, or oppressive conduct, although the precise terminology differs. Notwithstanding differences in language, courts have tended to interpret the showing required under these statutes in the same way. See infra notes 168, 196. For examples of oppression statutes which apply specifically to shareholders of close corporations, see Ga. Code ANN. $\$ 14-2-940$ (1989); MD. Corps. \& Ass'Ns Code ANN. §§ 4-603 (1985); MinN. STat. ANn. § 302A.751 subd. 2 (West Supp. 1990); Mont. Code Ann. § 35-9-501 (1989); N.J. Stat. Ann. § 14A:12-7 (West Supp. 1989); S.C. Code AnN. $\$ 33-18-400$ (Law. Co-op. Supp. 1988); Wis. Stat. Ann. $\S 180.995(19)$ (West Supp. 1989). For studies of oppression statutes, see Cheffins, The Oppression Remedy in Corporate Law: The Canadian Experience, 10 U. PA. J. INT'L Bus. L. 305 (1988); Hillman, The Dissatisfied Participant in the Solvent Business Venture: A Consideration of the Relative Permanence of Parinerships and Close Corporations, 67 MinN. L. REv. 1 (1982); Macdonald, Corporate Behavior and the Minority Shareholder: Contrasting Interpretations of Section 10-19.1-115 of the North Dakota Century Code, 62 N.D.L. REv. 155 (1986).

20 Ingle v. Glamore Motor Sales, Inc., 73 N.Y.2d 183, 535 N.E.2d 1311, 538 N.Y.S.2d 771 (1989), discussed infra notes $201-13$ and accompanying text, rather explicitly suggests the exclusivity of the oppression mode of analysis in close corporation law. See also Jordan v. Bowman Apple Products Co., 728 F. Supp. 409, 425-26 (W.D. Va. 1990) (finding Virginia oppression statute to be exclusive remedy that preempts common law oppression remedies); Toner v. Baltimore Envelope Co., 304 Md. 256, 273-80, 498 A.2d 642, 651-54 (1985) (rejecting plaintiff's common law theory that directors of close corporations had a duty to offer minority shareholders an equal opportunity to sell their shares because that theory was contrary to the approach of Maryland's oppression statute); Sundberg v. Lampert Lumber Co., 390 N.W.2d 352, 356-57 (Minn. Ct. App. 1986) (holding that the equitable remedy of redemption under the common law of corporations has been limited to situations in which the Minnesota oppression statute applies). Professor Cheffins has warned courts in the United States of the need to keep analysis of oppression separate from fiduciary analysis in close corporations. See Cheffins, supra note 19, at 337-38. As I shall demonstrate, courts have failed to distinguish the analyses.

21 The phrase is from Cardozo's famous passage in Meinhard v. Salmon, 249 N.Y. 458, 464, 164 N.E. 545, 546 (1928) (discussed infra at notes 67-97 and accompanying text). 
of corporate power holders in favor of rules protecting Holmes's "bad man" from unintentionally incurring liability. ${ }^{22}$ The result is a change in the goals of corporate law. ${ }^{23}$

Before analyzing these developments, I will, in Part I of this Article, set out the traditional parameters of the fiduciary relationship and its corresponding duty, and broadly identify the problems arising from attempts to analyze close corporation relationships within that context. In Part II, I will analyze courts' uses of fiduciary principles in resolving conflicts within close corporations, and demonstrate the subtle ways in which those principles have been replaced. In Part III, I will analyze proposals by scholars to resolve problems posed by fiduciary analysis in close corporation law, and demonstrate that at the heart of the debate is a philosophical disagreement over the propriety of applying to close corporations the norms underlying fiduciary principles. I will conclude by suggesting that the appropriate way to resolve, and, more importantly, prevent, close corporation conflicts is to impose fiduciary obligations on the controlling shareholders in their exercise of power and on minority shareholders in the exercise of their fiduciary rights, thus restoring the prophylactic function of fiduciary obligation as a supplement to existing remedies.

\section{In Search of Fiduciary Relationships}

Before I analyze the fate of fiduciary analysis in close corporations, it is necessary to develop some general notions about what a fiduciary relationship is. ${ }^{24}$ In so doing, I conclude that at the heart

22 Holmes, The Path of the Law, 10 HARv. L. REv. 457, 461 (1897).

23 Cf. Hetherington \& Dooley, supra note 10. Professors Hetherington and Dooley write: "A free enterprise: system is based on the assumption that optimal allocation of resources will result from the individual decisions of resource owners acting in their own perceived self-interests." Id. at 44. Perhaps. But the "resource owners" of a close corporation are owners in common, and a divergence of these interests may well split the firm, a. result which Professors Hetherington and Dooley apparently believe desirable (or at least necessary) to facilitate.

24 The various theories propounded by scholars to identify and define fiduciary relationships and the duties that How from them differ in their emphasis. Professor Shepherd sees the "essence" of fiduciary relationships as the notion "that powers are a species of property ...." J.C. SHEPHERD, supra note 1, at 35-36. Professor Brudney emphasizes the representational character of fiduciary relationships. See Brudney, Fiduciary Ideology, supra note 1, at 259-60. Professor Frankel focuses on the potential for abuse of power by the fiduciary as the core problem, and defines the relationship from that premise. See Frankel, supra note 1, at 797. In this sense, she and I share a general conception of the fiduciary relationship. Similar to Professor Frankel's (and to my) focus on the abuse of power is Professor Jacobson's assertion that the essence 
of this legal construct lie two assumptions about human nature-that persons can and will subordinate self-interest to the interests of others, ${ }^{25}$ and further that this is a social good the law can

of fiduciary relationships is "the shifting of judgment from one person to another." Jacobson, supra note 1 , at 620 .

Professor Davis analyzes fiduciary duty in part as a function of its enforcement, see Davis, supra note 1, at 3, but appears to define the broad notion of the fiduciary relationship as being "the device employed to restrict ... unfettered powers of persons who are entrusted with control over the assets and affairs of others." Id. at 1. Since he does not analyze this definition outside of the (to him) more important defining context of enforcement, I will not belabor the point.

Although they seem to describe the duty flowing from the relationship more than the relationship itself, Dean Clark identifies the following as the four "common attributes of the fiduciary relationship": "affirmative duties to disclose," "openended duties to act," "closed-in rights to positional advantages," and "moral rhetoric." Clark, supra note 1, at 71-76. Professor Anderson sees as the general characteristics of a fiduciary relationship the decisionmaking power of fiduciaries, the difficulty of subjecting those decisions to detailed standards, the frequent need for specialized information in making those decisions, and the fiduciary's potential to inflict losses on the beneficiaries. See Anderson, supra note 1, at 757-58.

Professor Scott describes a fiduciary relationship as one involving "a duty on the part of the fiduciary to act for the benefit of the other party to the relation as to matters within the scope of the relation." 2A A. SCOTT \& W. FRATCHER, supra note 1, $\S 2.5$. In this relationship, "[i]t is the duty of a trustee to administer the trust solely in the interest of the beneficiaries." Id. $\S 170$. Professor DeMott observes that "the law of fiduciary obligation is situation-specific. . .," DeMott, supra note 1, at 879, largely stemming from its equitable origins, see id. at $\mathbf{8 8 0}$. While she does not posit her own definition of the fiduciary relationship, though the broad parameters of her views are implicit in her criticisms of analogizing fiduciary duty to contract law, she does state that "[i]n many relationships in which one party is bound by a fiduciary obligation, the other party's vulnerability ... justifies the imposition of fiduciary obligation." Id. at 902 .

Professor Weinrib takes a functional approach and views fiduciary duty as performing the dual functions of controlling discretion and maintaining business integrity. See Weinrib, supra note 1, at 150. He sees these two elements as forming the "core" fiduciary concept of substantial discretion in the fiduciary which is "capable of affecting the legal position of the principal." Id. at 1.

Professor Shepherd has catalogued the principal competing theories of fiduciary duty. See J.C. ShepHERd, supra note 1, at 51-91; Shepherd, supra note 1, at 53-79. He has also made what $I$ believe to be a persuasive explanation of the law's failure to clearly define the fiduciary relationship:

Of course, part of the reason for this is that the concept is unusually difficult, being intrinsically non-rational. However, we must recognize that our reluctance [to define fiduciary relationships] to a large extent results from a fear that by defining the concept we will rob it of its dynamics and therefore its soul.

J.C. ShephERD, supra note 1, at 3. Judge Cardozo's opinion in Meinhard v. Salmon, 249 N.Y. 458, 164 N.E. 545 (1928), discussed infra at notes $67-97$ and accompanying text, exemplifies this last statement.

25 Cf. Hetherington, Defining the Scope, supra note 9, at 12 (stating that the "[fiduciary] obligation [of majority shareholders] is based in part on the cynical but 
encourage. These assumptions are absent from the new methods of analysis in close corporations.

A fiduciary relationship is a relationship of power and dependency in which the dependent party relies upon the power holder to conduct some aspect of a dependent's life over which the power holder has been given and accepted responsibility. ${ }^{26}$ The dependent, for a variety of reasons, has limited (or had limited for her) control over one or more aspects of her personal or economic life. ${ }^{27}$ The power holder is charged with assuming the power abdicated by (or not granted to) the dependent in the manner she deems will best fulfill her responsibility. ${ }^{28}$ The power holder has, in some sense, voluntarily undertaken the responsibilities with which she has been charged. ${ }^{29}$ The dependent's reliance upon the power holder or, not quite conversely, the power holder's service as a surrogate for the dependent, characterizes the fiduciary relationship.

The power holder must do for the dependent what the latter cannot, or will not, do for herself. ${ }^{30}$ Although this statement, shorn of context-specific labels, describes all economic and many legal relationships, two principal aspects of the fiduciary relationship are distinctive. First, a great deal of discretion is vested in the power holder. Except for the broad requirements of care and loyalty that set the parameters of the power holder's authority (and, in part, define the scope of her dury), the power holder has complete freedom to conduct that segment of the dependent's life over which she has been given responsibility. ${ }^{31}$ Second, not only will the power

realistic assumption that elected officers, in exercising their discretionary authority, will favor the interests of those whose votes elected them").

26 Professor Frankel uses the terminology of "power bearer" and "dependent" to describe what she refers to as a "status relation." See Frankel, supra note 1, at 798. I believe that this type of terminology applies to fiduciary relationships as well.

27 See Jacobson, supra note 1, at 617-18.

$28 \mathrm{See}$ id. at 620; cf. Anderson, supra note 1, at 757 (noting decision making power of fiduciary); Frankel, supra note 1, at 809 (stating that "the fiduciary obtains power from the entrustor or from a third party for the sole purpose of enabling the fiduciary to act effectively" (footnotes omitted)); Weinrib, supra note 1 , at 7 (observing that "the hallmark of a fiduciary relation is that the relative legal positions are such that one party is at the mercy of the other's discretion").

29 See Frankel, supra note 1, at 820 (arguing that a fiduciary voluntarily assumes her role); Shepherd, supra note 1 , at $64-68$ (criticizing fiduciary theory based principally on undertaking); $i d$. at 76 (accepting the requirement of an undertaking as part of theory).

30 See Jacobson, supra note 1, at 617; of. Frankel, supra note 1, at 808-09 (describing some of the purposes for which a fiduciary relationship may be created).

31 See Weinrib, supra note 1, at 4; cf. Anderson, supra note 1, at 757-58 (noting difficulty of cabining a fiduciary's cliscretion and potential for a fiduciary to harm the 
holder have responsibility over a specific aspect of the dependent's life, but in the typical fiduciary relationship, the dependent will be precluded from exercising any control over that area. ${ }^{32}$

These central components of the fiduciary relationship ${ }^{33}$ give rise to certain duties. Because the dependent (or a third party intending to benefit the dependent) is the source of the fiduciary's power, ${ }^{34}$ and because the relationship permits the power holder to control an aspect of the dependent's life, the power holder is obli-

beneficiary); Jacobson, supra note 1, at $622-23$ (arguing that the duties of loyalty, care, and prudence bound the exercise of a fiduciary's discretion).

32 See Frankel, supra note 1, at 832 (discussing the inability of the entrustor to protect herself). Compare Clark, supra note 1, at 57-58 (discussing the very limited rights of participation possessed by shareholders in public corporations) with Frankel, supra note 1, at 809-10 (focusing on the quantum of power granted to the fiduciary rather than the exclusion of the dependent from the exercise of the powers).

The power of a principal to control her agent, see Clark, supra note 1, at 56, does not invalidate this characteristic because, although the principal may control the agent or even act within the area of delegated authority, this control or activity may have limited effect, if any, on the agent's ability to bind the principal. See W. Cary \& M. Eisenberg, Cases and Materials On Corporations 9-16 (6th ed. unabr. 1988) (providing a summary of rules concerning an agent's power to bind a principal to an agent's actions notwithstanding lack of authority to do so).

33 Although various theorists have identified the characteristics of fiduciary relationships in a number of ways, I believe that my "central components" are the irreducible minima of each of the theories. Of particular importance is the fact that the commentators unanimously agree that the fiduciary is obligated to act in the beneficiary's best interests. As to (i) the obligation of the fiduciary to act for the beneficiary, see Clark, supra note 1, at 73; Davis, supra note 1, at 19; DeMott, supra note 1, at 882; Frankel, supra note 1, at 808; Scott supra note 1, at 540; Shepherd, supra note 1, at 75; Weinrib, supra note 1, at 4-5; (ii) the capacity of the fiduciary to pursue this interest, see Jacobson, supra note 1 , at 616 (stating that in the fiduciary relation the actions of the fiduciary must "be prosecuted only by persons capable of exercising judgment"); Davis, supra note 1, at 40-41 (analyzing commonality of interests of "concentrated-constituency principals" as contrasted with "diffusedconstituency principals"); (iii) the delegation of the beneficiary's power or responsibility to the fiduciary, see Brudney, Fiduciary Ideology, supra note 1, at 259-60; Jacobson, supra note 1, at 619; Shepherd, supra note 1, at 77-78; $f f$. Frankel, supra note 1 , at 800 (emphasizing dependence of the beneficiary on the fiduciary); (iv) the transfer of power to the fiduciary, see Frankel, supra note 1, at 809; Jacobson, supra note 1, at $616 \mathrm{n} .48$; Shepherd, supra note 1, at 75; (v) the fiduciary's volition in entering into the relationship, see J.C. SHEPHERD, supra note 1, at 100-01; Scott, supra note 1 , at 540; $c$. Clark, supra note 1, at 61-62 (describing "three grades of consent"); Jacobson, supra note 1 , at 635 (noting that the fiduciary does not accept duty, rather the law imposes it); (vi) the exercise of discretion by the fiduciary, see Anderson, supra note 1, at 757-59; Clark, supra note 1, at 77; Weinrib, supra note 1, at 4; (vii) extended duration of the relationship, see Frankel, supra note 1, at 817 n.62; (viii) preclusion of the beneficiary from acting with respect to the delegated matter, see Jacobson, supra note 1, at 617-18; cf. Clark, supra note 1, at 57-58 (discussing limited ability of public corporation shareholder to participate in management).

34 But see Jacobson, supra note 1, at 621 (describing the source of fiduciary obligation as the sovereign). 
gated to act in the dependent's interest, and not her own, in exercising that power. ${ }^{35}$

The obligation of the power holder to act in the dependent's best interests suggests an underlying assumption of fiduciary law, that the power holder is able to act in the dependent's best interests. Fiduciary principles are based on the assumption that the power holder can put aside any personal interests in a given situation and adopt a course of conduct designed exclusively to serve the best interests of the dependent. These principles are based upon the further assumption that such persons will, in fact, do so. ${ }^{36}$ Without these assumptions, the prophylactic function of fiduciary duty ${ }^{37}$ becomes impractical, and the enforcement of fiduciary duties is

35 See 2A A. ScotT \& W. FRATChER, supra note 1, § 170; Jacobson, supra note 1, at 621; see also In re Hubbell, 302 N.Y. 246, 254, 97 N.E.2d 888, 891 (1951) (dealing with fiduciary principle in trust context); Wendt v. Fischer, 243 N.Y. 439, 443-44, 154 N.E. 303, 304 (1926) (dealing with fiduciary principle in the agency context); Hoover, Basic Principles Underlying Duty of Loyalty, 5 Clev.-Marshall L. Rev. 7 (1956); of. Anderson, supra note 1, at $746 \mathrm{n} .26$ (noting frequent "strong moral overtones" in descriptions of fiduciary duty); id. at 759 ("In a fiduciary relationship, the client or beneficiary depends on the fiduciary to an unusual degree to determine for the client what his best interests are."); Weinrib, supra note 1, at 11 (identifying courts' concern with "apparent immorality of the defendant's reaping where he had not sown").

Judge Hoover reduced fiduciary duty to a "duty of disinterested judgment" and identified two questions as a rule of thumb for detecting violations of this duty: "(1) Does the trustee have a conflict of interest? and (2) Can the trustee render a disinterested judgment?" Hoover, supra, at 10.

The requirement that the power bearer act in the dependent's best interests does not mean that the power bearer must act as the dependent would have acted were she exercising the power herself. If that were the case either the person delegating the power would have circumscribed it by giving the power bearer specific detailed directions for its exercise, or else she never would have delegated it. $C f$. Frankel, supra note 1, at 813-14 (explaining that beneficiaries are not able to exercise control over fiduciaries); Weinrib, supra note 1 , at 7 (asserting that if the fiduciary is so bound by instructions so as to have no discretion, the fiduciary relationship cannot come into being). Rather, the power bearer is to exercise her authority in a manner that, in her judgment, is calculated best to serve the dependent's interests.

36 See, e.g., Frankel, supra note 1, at 830 (stating that "[o]nce a person becomes a fiduciary, the law places him in the role of a moral person and pressures him to behave in a selfless fashion, to think and act for others"). But see Jacobson, supra note 1, at 621-22 (arguing that it is impcossible for the fiduciary to identify the beneficiary's best interest, and that the fiduciary is therefore bound to protect "an interest imputed to the beneficiary by public authority").

37 See, e.g., Lindenhurst Drugs, Inc. v. Becker, 154 Ill. App. 3d 61, 68, 506 N.E.2d 645, 650 (1987) (stating that the "prophylactic purpose of the rule imposing a fiduciary obligation" is frustrated if directors fail to disclose a corporate opportunity and exploit that opportunity for their own purposes (quoting Kerrigan v. Unity Savings Assoc., 58 Ill. 2d 20, 28, 317 N.E.2d 39, 43 (1974))). 
doomed to regular litigation. Instead, the law assumes a high degree of altruism on the part of the fiduciary.

When the fiduciary and the beneficiary share ownership interests in the property around which the relationship centers, this basic assumption becomes strained. ${ }^{38}$ Of course, conflicts of interest will often exist between individuals, and there is no reason to suspect that this will change simply because a relationship is denominated as fiduciary. ${ }^{39}$ The traditional solution of fiduciary analysis has been to disqualify the fiduciary from receiving any benefits from the relationship. This relieves the fiduciary of having to balance her own interests against those of her beneficiary and simplifies judicial analysis. ${ }^{40}$ This solution reflects the view that requiring self-denial from the fiduciary is a social good. The price of enforcing this standard, however, is some loss of efficiency, a consequence which may explain the general trend in corporate law away from strict fiduciary standards to more permissive rules. ${ }^{41}$

Although efficiency loss may be the price of imposing strict fiduciary standards in the general corporate context, the approach

38 Professors Hetherington and Dooley believe that " $t]$ o expect the majority not to take some advantage of the exploitative potential of its position is unreasonable and unrealistic." Hetherington \& Dooley, supra note 10 , at 35 .

39 Cf. Anderson, supra note 1, at 738 ("All individuals who engage in transactions with others have conflicts of interest-conflicts between self-interest and their legal duties to other persons." (footnote omitted)).

40 See DeMott, supra note 1, at 882. Professor Scott suggests that fiduciary relationships vary in intensity. See $2 A$ A. Scotr \& W. Fratcher, supra note 1, § 170; Scott, supra note 1, at 541. In Scott's view, the intensity of the duty varies with the "independent authority to be exercised by the fiduciary." Id.; see also Renz v. Beeman, 589 F.2d 735, 744 (2d Cir. 1978) (distinguishing in the context of a trust the circumstances under which the lesser duty of good faith will be applied from those in which a strict duty of loyalty applies). Scott, however, also states that it is basic to fiduciary duty that the fiduciary act in the beneficiary's best interests. See 2A A. ScotT \& W. Fratcher, supra note 1, §§ 170, 170.25; see also Michoud v. Girod, 45 U.S. (4 How.) 502, 554 (1846) (in a case concerning the fiduciary's purchase of entrusted property, stating that " $[t]$ he general rule stands upon our great moral obligation to refrain from placing ourselves in relations which ordinarily excite a conflict between self-interest and integrity"); $f f$. Renz, 589 F.2d at 745 ("Absent exculpation or clear consent, it is the existence of the conflict alone that establishes the obligation."). As described in Renz, the duty varies between an "undivided loyalty" standard and a standard of good faith, with the latter permitting the courts to examine the merits of a transaction. See id. at 744-45. It is this latter good faith standard which is most frequently expressed in close corporation cases. I will show, however, that this standard has been eroded further in corporate law to the point where a fiduciary has complied with her duty as long as there is an absence of bad faith. See infra notes 47213 and accompanying text.

41 See Bulbulia \& Pinto, Statutory Responses to Interested Directors' Transactions: A Watering Down of Fiduciary Standards?, 53 Notre Dame Law. 201, 203-04 (1977); Brudney, Fiduciary Ideology, supra note 1, at $261 \mathrm{n.8.}$ 
presents a more serious problem in close corporations. The application of strict fiduciary staridards to close corporations deprives controlling shareholders of the ability to manage the corporation-to use their own property-as they see fit. Because of the apparent unfairness of this result and the difficulty courts face in distinguishing actions taken in the best interests of the corporation and shareholders from those which impinge unfairly on the minority, ${ }^{42}$ courts have begun to reverse the analysis and require the power holder simply to avoid "low" levels of conduct. ${ }^{43}$ Ultimately this represents an abandonment of the prophylactic function of fiduciary duty and its underlying assumptions. ${ }^{44}$

Although judges increasingly depart from fiduciary analysis in resolving close corporation conflicts, they nevertheless have been reluctant to abandon fiduciary terminology. ${ }^{45}$ This trend may dilute fiduciary principles generally as they apply in other contexts. In addition, it obscures the underlying philosophical changes reflected in the new tests and results in misdirected normative evaluations of those tests. Finally, it suggests that the terminology implies a standard of conduct from which courts overtly are reluctant to depart, even if the actual resolution of disputes is based on other factors. ${ }^{46}$ Thus, in Part II, I will refine my analysis of the problems that fiduciary duty causes in close corporations, trace the transformation of fiduciary principles, and explain the new vision of corporate ethics now embodied in fiduciary rhetoric.

\section{Fiduciary Analysis in Close Corporations}

In the application of fiduciary principles in corporate law, there has been a clear tendency to move from the broad articulation of

42 See Hetherington \& Dooley, supra note 10, at 39 (explaining that the majority will vote out managers who have breached their fiduciary duty).

43 See infra notes 165-213 and accompanying text.

44 See infra notes 98-164 and accompanying text.

45 For an insightful explanation of this trend, see Chiles v. Robertson, 94 Or. App. 604, 619-20, 767 P.2d 903, 911-12 (1989). For examples of cases equating "oppression" with breach of fiduciary duty, see infra note 169. See also Macdonald, supra note 19, at 171 (noting that the expanded definition of "[o]ppression became a more attractive avenue for relief" with courts beginning "to acknowledge that if the controlling shareholders breached their fiduciary duty to the minority shareholders, oppression resulted").

46 Professor Weinrib's theory of a primary and secondary policy underlying fiduciary duty, with the latter being the maintenance of the integrity of business institutions, provides an interesting explanation of this phenomenon. See Weinrib, supra note 1, at 3-15; see also Clark, supra note 1, at 75-76 (describing the moral rhetoric often employed in judicial opinions dealing with fiduciary duty). 
fiduciary principles applicable to directors and controlling shareholders to the formulation of transactional rules that work to balance the interests of controlling persons with those of minority shareholders. ${ }^{47}$ The trend, however, has lagged in the law of close corporations.

The corporate law fiduciary rules applicable to public corporations generally apply equally to close corporations. For example, the corporate opportunities doctrine, ${ }^{48}$ statutes dealing with interested director transactions and other forms of self-dealing, ${ }^{49}$ rules governing freeze-out mergers, ${ }^{50}$ and the general anti-fraud provision of the Securities and Exchange Act of $1934,{ }^{51}$ all apply to close corpo-

47 See Marsh, Are Directors Trustees?-Confict of Interest and Corporate Morality, 22 Bus. LAw. 35, 36-43 (1966). In this well-known article, Mr. Marsh traces the development of fiduciary rules governing transactions between a corporation and a director or her affiliate, and shows the progress from pure prohibition of such transactions in the classic fiduciary manner to contemporary legislation permitting such transactions upon compliance with statutory procedures. An issue exists under these statutes, however, as to whether substantive fairness to the corporation must be demonstrated even given the fact of procedural compliance. The commentary to the Revised Model Business Corporations Act appears to envision application of the fairness test only when the statutory procedures have not been followed. See Rev. Model. Business CoRP. ACT $\$ 8.31$ official comment 1 (1984); see also Branson, supra note 11, at 387 (arguing that the American Bar Association is attempting to negate the duty of loyalty of directors); Bulbulia \& Pinto, supra note 41 (examining interested director statutes); Davis, supra note 1, at 50-52 (noting that doctrines like informed consent have "operat[ed] to waive the pure prohibition" of certain transactions and that courts have eased "the level of judicial scrutiny to ad hoc fairness review"). The development of balancing tests in close corporations is discussed later. See infra notes 98-164 and accompanying text.

48 See Irving Trust Co. v. Deutsch, 73 F.2d 121, 123-24 (2d Cir. 1934); Klinicki v. Lundgren, 298 Or. 662, 663, 695 P.2d 906, 907 (1985); Guth v. Loft, 23 Del. Ch. 255, 5 A.2d 503, 510-12 (1939). But see Brudney \& Clark, $A$ New Look at Corporate Opportunities, 94 Harv. L. REv. 997, 1000, 1006-22 (1981) (noting "that different considerations and rules should be employed for close corporations than for publicly held corporations" in applying the corporate opportunities doctrine, and proposing specific guidelines for the doctrine's application); Note, Corporate Opportunity in the Close Corporation-A Different Result?, 56 GEo. L.J. 381, 388-91 (1967) (arguing for special and separate treatment of close corporations under the law of corporate opportunities).

49 See, e.g., Del. Code ANN. tit. 8, § 144 (1983); N.Y. Bus. Corp. LAw § 713 (McKinney 1986); ALI Principles of Corporate Governance $\$ 5.02$ (Tent. Draft No. 5 1986); Rev. Model Business Corp. AGt $\$ 8.31$ (1984).

50 See, e.g., Alpert v. 28 Williams St. Corp., 63 N.Y.2d 557, 568-69, 473 N.E.2d $19,25-27,483$ N.Y.S.2d 667, 673-74 (1984) (stating that "[a]s a general matter" all corporate directors have a duty of fair dealing in merger decisions); $c f$. Leader $\mathrm{v}$. Hycor, Inc., 395 Mass. 215, 222-23, 479 N.E.2d 173, 177 (1985) (stating that the duty of "utmost good faith and loyalty" applies to directors of close corporations).

5115 U.S.C. $\$ 78 \mathrm{j}(\mathrm{b})$ (1988). Application of the Securities and Exchange Act to close corporations is discussed in Brudney, Fiduciary Ideology, supra note 1, at 289-94. 
rations. The fiduciary rules of corporate law address situations in which potential conflicts of interest (omnipresent between directors and shareholders) become actualized. ${ }^{52}$ These situations, and therefore the rules, are exceptional, because they depart from the ordinary legal freedom of directors to manage or supervise the corporation's business. ${ }^{53}$ Normally business decisions, such as product development and new investments, do not present these conflicts and therefore are unimpeded by fiduciary rules. Distributional decisions, such as the payment of dividends and the redemption of stock, present a different opportunity for self-serving conduct in that they might be resolved disproportionately. These situations, however, are relatively easy to identify and correct. ${ }^{54}$

Close corporations, though, present a special problem. Close corporation shareholders tend to have invested substantial personal wealth in the enterprise, ${ }^{55}$ magnifying the consequences of any business decision as to a particular shareholder. Thus, any meaningful distinction between business decisions and distributional decisions becomes more difficult to make. ${ }^{56}$ Given significant stock ownership by close corporation management, ${ }^{57}$ the potential for conflicts of interest between director shareholders and non-director shareholders, or even among director shareholders themselves, over a given decision (business or distributional) is pervasive. ${ }^{58}$ While in the public issue corporation we still might talk about the best interests of the corporation, if for no other reason than as a shorthand for the lowest common denominator of shareholder interest, ${ }^{59}$ in the paradigmatic

See generally Ruder, supra note 1, at 1398-99 (discussing application of the Securities and Exchange Act).

52 See J.C. SHEPHERD, supra note 1, at 339.

53 See, e.g., Del. Code AnN. tit. 8, \& 141 (a) (1983).

54 Courts, at times, have been unable or unwilling to recognize that differences between close corporations and publicly held corporations may require a reexamination of certain corporate doctrines. For example, the distinction between business and distributional decisions becomes more difficult to make in the close corporation context; yet, the law has not fully recognized and addressed the problem. See Chittur, Resolving Close Corporation Conficts: A Fresh Approach, 10 HaRv. J.L. \& PuB. PoL'y 129, 152-65 (1987).

55 This is generally accepted as one of the defining characteristics of close corporations. See Mitchell, supra note 4, at 1151.

56 See Chittur, supra note 54, at 152-65.

57 A further accepted defining characteristic of close corporations is some congruity between ownership and management. See Mitchell, supra note 4, at 1151 .

58 I discuss in another article the problem of lawyers' conflicts of interest in the context of counselling close corporations and their shareholders. See Mitchell, Professional Responsibility and the Close Corporation: Toward a Realistic Ethic, 74 ConNell L. REv. 466 (1989).

59 See, e.g., Dodge v. Ford Motor Co., 204 Mich. 459, 506-07, 170 N.W. 668, 684 
close corporation no discernable corporate interest exists apart from the individual interests of the shareholders at any given point in time. ${ }^{60}$ In the absence of any regulatory mechanism, internal disagreements degenerate into power struggles. ${ }^{61}$

As long as corporate distributions are proportional, or the shareholders agree that a particular business decision (including the decision to make a given distribution) is desirable, the interests of the power holder and the dependent will be congruent and no problem will arise. When distributions are disproportionate, or when business interests diverge, however, the dependent may feel that the power holder's conduct is contrary to her best interests. The problem is compounded when the power holder/decisionmaker has no specialized knowledge, or no greater expertise than the dependent/ minority shareholder, or when the decision requires no such specialized knowledge or expertise. ${ }^{62}$ In such situations, there is no reason to suppose that the power holder can make a decision regarding the dependent's best interests better than the dependent herself. ${ }^{63}$ Thus, without an expectation or requirement that the power holder subjugate her own judgment to that of the dependent, extra-judicial dispute resolution becomes a simple power struggle, with the weaker side inevitably losing. ${ }^{64}$

(1919) (stating that courts must defer to directors' business decisions because "judges are not business experts"); $c f$. Branson, supra note 11, at 387-88 (arguing that the ABA amendments to the Model Business Corporation Act have excluded from the definition of "conflicting interest transactions" many transactions that "by common sense usually involve conflicts of interest" thereby resulting in the reduction of business morality to the lowest common denominator).

60 See generally Chittur, supra note 54.

61 Cf. Branson, supra note 11, at 377 (stating that "without articulated brackets around private ordering, the legal boundary presumably is simple majoritarian shareholder rule").

$62^{\circ}$ For an illustration of the difficulty of resolving problems in this context, see Smith v. Atlantic Properties, Inc., 12 Mass. App. Ct. 201, 422 N.E.2d 798 (1981), discussed infra notes 154-64 and accompanying text.

63 The diminished importance of expertise and specialization of function in close corporations, see Fama \& Jensen, Agency Problems and Residual Claims, 26 J. LAw \& Econ. 327 (1983), is strong support for the argument that the business judgment rule should not be applied in that context, see Chittur, supra note 54, at 129; see also Hetherington \& Dooley, supra note 10, at 2 (noting the relative ease with which close corporation shareholders can monitor the corporation's affairs).

64 This is a slight overstatement. The dependent will have the informal opportunity to persuade the power bearer of the correctness of her view although she lacks means within the corporate structure to effect that view. She is, in other words, reliant upon the good faith of the power bearer to see that a given course of action does not unfairly affect her. Cf. Hetherington \& Dooley, supra note 10, at 5 ("In close corporations, the majority is in a position to cause a wealth transfer to itself from the minority at any time."). 
Fiduciary duty provides standards designed to mediate this power struggle. ${ }^{65}$ But confronted with the same problem of balancing legitimate competing interests faced by close corporation shareholders, and the fact that traditional rules of corporate governance giving control to the majcrity apply to close corporations, courts have retreated from attempts to enforce high standards of fiduciary conduct. Instead they have begun to ratify the actions of the more powerful party, unless the minority can demonstrate bad faith or willful misconduct. ${ }^{66}$

In this section, I will analyze the traditional understanding of fiduciary duty typified by the classic case of Meinhard v. Salmon. Then, I will develop the three stages of fiduciary analysis in close corporations, starting with the classic application, progressing to the balancing of interests stage, and concluding with the current stage defining breach of fiduciary duty as affirmative misconduct. In doing so, I will thereby show how the problem of fiduciary analysis in close corporations has led courts to transform fiduciary principles into actions resembling intentional tort.

\section{A. Fiduciary Duty as Moral Precept-The Theme of Meinhard v. Salmon}

Perhaps the most potent influence on the early development of fiduciary principles in close corporation law, and the classic exposition of that duty as moral precept, is Judge Cardozo's opinion in the 1928 case of Meinhard v. Salmon. ${ }^{67}$ Although Meinhard is the oldest war-horse in the repertoire of corporate fiduciary duty and is often quoted, ${ }^{68}$ it is rarely analyzed. Its important influence on the devel-

65 An action for breach of fiduciary duty is only one of several actions available to a complaining shareholder. See Hillman, supra note 19, at 38-39 (listing variety of actions for relief available to minonity shareholders). Part of the problem this Article seeks to address is the extent to which the independent action for breach of fiduciary duty has been subsumed analytically within these other remedies.

66 Shepherd suggests that it is not the "intentions of the oppressor that are relevant, but the effect of the oppressor's actions on the minority." J.C. SHEPHERD, supra note 1 , at 369 . As should be clear from the preceding discussion, I believe that this does not substantially aid fiduciary analysis in close corporations and is inconsistent with actual judicial treatment. I do believe, however, that his observation leads in the right direction.

67249 N.Y. 458,164 N.E. 545 (1928).

68 DeMott describes Meinhard as "[p]robably the example [of cases using the language of moral obligation in applying fiduciary principles] best known to lawyers in the United States ...." See Demott, supra note 1, at 891 n.56; see also Ruder, supra note 1, at 1386 (quoting Meinhard in his general description of the duty of loyalty). 
opment of the law ${ }^{69}$ dictates fresh analysis before proceeding to examine that development.

Meinhard did not involve a corporation at all, but a joint venture between Morton Meinhard and Walter Salmon for the purpose of leasing, altering, and managing a piece of commercial real estate in New York City for a term of twenty years. Salmon had located the property and invited Meinhard to join him, on terms whereby Meinhard would supply half the requisite funds and receive a portion of the profits. "Salmon, however, was to have sole power to 'manage, lease, underlet and operate' the building."70 The relationship established thus exhibits the characteristics of a fiduciary relationship: Meinhard delegated to Salmon the exclusive power to regulate a portion of Meinhard's economic life for a period of years. It also exhibits the intractable problem of close corporation relationships: Salmon, the fiduciary, had a substantial economic interest in this very same project.

Toward the end of the lease term, Salmon, unbeknownst to Meinhard, entered into a new agreement with the property's owner not only to continue to lease the property, ${ }^{71}$ but also to lease adjacent properties. The new twenty year lease was subject to three successive renewals, ultimately extending the lease to eighty years. ${ }^{72}$

The court held that Salmon's failure to disclose the existence of this new opportunity to Meinhard was a breach fiduciary duty. "The trouble about his conduct [was] that he excluded his coadventurer from any chance to compete, from any chance to enjoy the opportunity for benefit that had come to him alone by virtue of his agency. This chance, if nothing more, he was under a duty to concede."73 Consequently, the court imposed a constructive trust on the new lease entitling Meinhard to his pro rata share of the proceeds of the new venture upon payment of his share of the expenses. ${ }^{74}$ The court did not deny that Salmon's interest in the new project was legitimate. Nor did it hold that that interest was subordinate to Meinhard's or to

69 See DeMott, supra note 1 , at 891 n.56.

70 Meinhard, 249 N.Y. at 462, 164 N.E. at 546.

71 It does not appear from the facts described in the opinion that the lease was renewable. Rather, Cardozo viewed the project as a "preemptive opportunity" that was an "incident of the enterprise." See id. at 464, 164 N.E. at 547.

72 See id. at 463,164 N.E. at 546.

73 Id. at 465,164 N.E. at 547.

74 See id. at 469,164 N.E. at 548-49. It is not clear in what capacity Meinhard was a fiduciary. Although Cardozo said it was as "managing coadventurer," $i d$. at 468,164 N.E. at 548 , his reference to agency in the previously quoted sentence suggests the possibility that Meinhard's fiduciary role was as an agent. 
that of the joint enterprise. Rather, it held that, at a minimum, each party had an equal right to be informed of, and independently compete for, the new project.

More significant than the facts or the holding of the case is the language Cardozo used to describe the duty. Of course no duty at all would apply unless Salmon were a fiduciary, a fact that Cardozo quickly established ${ }^{75}$ over Judge Andrews's dissent. ${ }^{76}$ Having done so, he turned to the scope of the duty. On the facts of the case, he simply could have analogized to the doctrines of partnership opportunity and corporate opportunity and held that because the new lease was sufficiently similar to the old, Salmon was obligated to acquire it for the joint venture. ${ }^{77}$ Instead, Cardozo imposed the far less demanding duty of disclosure on Salmon. ${ }^{78}$ In doing so, however, Cardozo expressly eschewed any opportunity to delimit the duty with specific rules: "Equity refuses to confine within the bounds of classified transactions its precept of a loyalty that is undivided and unselfish."79 Instead he interdicted Salmon's conduct by applying broad fiduciary principles, elegantly articulated in this now famous passage:

Joint adventurers, like copartners, owe to one another, while the enterprise continues, the duty of the finest loyalty. Many forms of conduct permissible in a workaday world for those acting at arm's length, are forbidden to those bound by fiduciary ties ... . Not honesty alone, but the punctilio of an honor the most sensitive, is then the standard of behavior. ${ }^{80}$

Of equal importance to the breadth of this standard is Cardozo's assertion of judicial willingness to apply it strictly:

75 See id. at 462,164 N.E. at 546.

76 Judge Andrews conceded that a fiduciary relationship existed between Meinhard and Salmon within the scope of the joint venture, but appeared to base his analysis more on contractual principles (particularly evidenced by his focus on the parties' intent) narrowly circumscribing the scope of the venture, than on broader fiduciary principles. See id. at 472-80, 164 N.E. at 549-52 (Andrews, J., dissenting).

77 The Appellate Division appears to have applied this reasoning. See Meinhard v. Salmon, 223 A.D. $663,667,229$ N.Y.S. 345,349 (1928), modified, 249 N.Y. 458,164 N.E. 545 (1928); see also Mitchell v. Reed, 61 N.Y. 123, 129 (1874) ("It has long been settled by adjudications that generally when one partner obtains the renewal of a partnership lease secretly, in his own name, he will be held a trustee for the firm, in the renewed lease.").

78 In so doing, Cardozo expressly refused to address the question of what Salmon's duty would have been had he disclosed the new lease to Meinhard. See Meinhard, 249 N.Y at $464-65,164$ N.E. at 547.

79 Id. at 467,164 N.E. at 548.

80 Id. at $463-64,164$ N.E. at 546. 
As to this there has developed a tradition that is unbending and inveterate. Uncompromising rigidity has been the attitude of courts of equity when petitioned to undermine the rule of undivided loyalty by the 'disintegrating erosion' of particular exceptions. Only thus has the level of conduct for fiduciaries been kept at a level higher than that trodden by the crowd. It will not consciously be lowered by any judgment of this court. ${ }^{81}$

It no longer matters whether Meinhard was correctly decided on the facts of the case. What does matter is Cardozo's establishment of two general principles in a case that did not require the announcement of these principles: (i) fiduciary duty is a moral precept of the highest order; and (ii) no exceptions to that duty will be entertained. $^{82}$ Also significant is the influence this opinion has had on the application and development of fiduciary principles and corporate law.

The rhetoric of the opinion, rather than its technical holding, causes the problems. ${ }^{83}$ It is broad, moralistic, and goes far beyond that necessary to find a simple breach of a duty to disclose. ${ }^{84}$ This duty would be fairly limited and would provide a bright-line standard

81 Id. at 464, 164 N.E. at 546 (citation omitted). But cf. Ingle v. Glamore Motor Sales Inc., 73 N.Y.2d 183, 189, 535 N.E.2d 1311, 1314, 538 N.Y.S.2d 771, 774 (1989) (suggesting that no fiduciary relationship exists among close corporation shareholders); Gallagher v. Lambert, 74 N.Y.2d 562, 565-67, 549 N.E.2d 136, 136 37, 549 N.Y.S.2d 945, 945-46 (1989) (same); Schwartz v. Marien, 37 N.Y.2d 487, 492, 335 N.E.2d 334, 338, 373 N.Y.S.2d 122, 127 (1975) (adopting business purpose test).

82 Cardozo had previously expressed similar ideas. See B. Cardozo, The Nature Of The Judicial Process 133-34 (1921) ("What really matters is this, that the judge is under a duty, within the limits of his power of innovation, to maintain a relation between law and morals, between the precepts of jurisprudence and those of reason and good conscience."); id. at 109-10 (distinguishing the judge's role in enforcing morality-laden doctrines like fiduciary duty from other legal principles).

83 Judge Easterbrook and Professor Fischel criticize similar "rhetoric" in Donahue v. Rodd Electrotype Co., 367 Mass. 578, 328 N.E.2d 505 (1975), see infra notes 103-28 and accompanying text, for obscuring clear analysis and being impossible to administer. See Easterbrook \& Fischel, Close Corporations and Agency Costs, 38 STAN. L. REv. 271, 294-95 (1986). While I agree with their analysis of Donahue, see infra note 151 , I believe their problem is more with the underlying philosophy expressed by that rhetoric than with its analytical paucity, see DeMott, supra note 1, at $881-82$ ("As a result of . . . history, the development of the adjective law of fiduciary obligation is inseparably a part of the obligation's substantive content." (footnote omitted)).

84 It is worth noting, in support of Cardozo's indignation, that construction of Grand Central Terminal, a mere two blocks from the subject property, was begun the year after Meinhard and Salmon began their relationship and was completed during the original lease term. See Columbia University, The New Columbia ENCYCLOPEDIA 2931 (4th ed. 1975). 
for the fiduciary's conduct. Cardozo, however, clearly viewed active compliance with fiduciary norms as a moral imperative. ${ }^{85}$ The language expressing these norms is aspirational and studiously imprecise. The very ambiguity of the language conveys its moral content as the court's refusal to ser lines is designed to discourage marginal conduct by making it difficult for a fiduciary to determine the point at which self-serving conduct will be prohibited, and thus to encourage conduct well within the borders. ${ }^{86}$

One of the most perceptive and articulate acknowledgments of this aspirational function of Meinhard's language is Judge Warren's opinion for the Oregon Court of Appeals in Chiles v. Robertson: ${ }^{87}$

Issues of whether a corporate officer or controlling shareholder has fulfilled fiduciary duties have arisen in a number of circumstances and have led to the creation of various specific rules. Courts, however, are not willing to say that a fiduciary fulfills its duties simply by following those rules. Opinions pile phrase upon phrase in what appears to some observers to be a mere compilation of platitudes. Yet those platitudes express something deeper; they are a judicial attempt to emphasize that the heart of a corporate fiduciary's duty is an attitude, not a rule. The fiduciary best fulfills its duties if it approaches them with the attitude of seeking the beneficiary's interests rather than the personal interests of the fiduciary, not if it simply tries to follow rules codified from past decisions. ${ }^{88}$

85 See supra note 82 and accompanying text.

86 Professor Hetherington is highly critical of the "vehemence" of this language, claiming it arises from the difficulty courts have in delineating the boundaries of fiduciary duty. See Hetherington, Defining the Scope, supra note 9, at 11 . He misses the point that this language is, in some sense, perfectly descriptive of fiduciary duty and is designed to enhance its prophylactic function. See DeMott, supra note 1, at 881 (discussing the development of the fiduciary duty in equity). Hetherington's treatment of fiduciary duty as remedial is the cause of his error. See Hetherington, Defining the Scope, supra note 9, at 11 . Hetherington notes that: "Where content and limits of rules are clear, one need only state the rule." Id. at 11 . One is left to wonder which rules of law Professor Hetherington believes to be selfexecuting. For further criticism of Hetherington's views, see infra notes 233-43 and accompanying text.

8794 Or. App. 604, 767 P.2d 903, review denied, 308 Or. 592, 784 P.2d 1099 (1989).

88 Id. at 619,767 P.2d at 911.12 (citations omitted). Judge Warren goes on to quote "the passage" from Meinhard. See id. at 619-20, 767 P.2d at 912. In this respect, the Meinhard opinion exemplifies Weinrib's secondary policy of fiduciary duty as maintaining business integrity. See Weinrib, supra note 1, at 9-15 (discussing the breadth of fiduciary duty law in protecting the integrity of commercial organizations); see also 2A A. SCOTT \& W. Fratcher, supra note $1, \$ 170.25$ (quoting Meinhard $v$. Salmon in a discussion of the fiduciary duties of trustees); Frankel, supra note 1, at 829-32 (dealing with the moral content of fiduciary duty). For a polemical exposition on the moral implications of the duty of loyalty, see Hoover, supra note 35. 
It is difficult to inspire and enforce this attitude when, in fact, it is expressed by a "compilation of platitudes," but judicial analysis actually occurs on a different plane. ${ }^{89}$ In close corporations, courts have bowed before the practical difficulties of enforcing this attitude against fiduciaries who have an interest in the subject property. ${ }^{90}$

The practical difficulties are not especially evident in Meinhard. The new lease entered into by Salmon was not a transaction in the ordinary course of business, nor would it have any effect upon the way in which the business of his joint venture with Meinhard was conducted. Thus it would be difficult to argue that Salmon's actions were in any way designed to further the interests of the joint venture, let alone Meinhard as the beneficiary of a fiduciary duty. Salmon's actions had no apparent motive other than self-interest. Therefore, the case does not present the practical problems of fiduciary analysis that exist where the fiduciary with a common interest in the property arguably acts in the interests of the beneficiary while benefiting himself.

If Meinhard were taken simply for its narrow holding, the absence of these practical problems would make the case doctrinally insignificant. The broader purposes for which it is cited, however, cause both practical and doctrinal problems when the challenged actions or transactions are less obviously self-interested, less completely independent of the ordinary course of business, and when the fiduciary's conduct is arguably beneficial to the enterprise as a whole. It is clear that trustees are prohibited from self-dealing in trust property, and that non-trustee fiduciaries have been subjected to the same general principle. Extension of this principle to corporate directors poses no theoretical problem for, as directors, they owe duties to the corporation they serve and its shareholders, not to themselves. ${ }^{91}$ Extension of this duty to corporate directors who are also significant shareholders, however, does present a problem. As directors, their duties are to the corporation. As shareholders, they are also beneficiaries of the duty owed by the directors to the corpo-

89 Cf. Easterbrook \& Fischel, supra note 83, at 295 (arguing that the court's "zeal to articulate a strict standard of fiduciary duty to protect minority shareholders in closely held corporations led it to ignore the reasons for fiduciary duties").

90 See, e.g., Chiles, 94 Or. App. at 620, 767 P.2d at 912 ("Our primary focus . . is necessarily on the specific rules that courts have created in the process of applying the implications of the fiduciary attitude .... No rule, however, can substitute for the 'punctilio of an honor the most sensitive.' "(quoting Meinhard, 249 N.Y. at 464, 164 N.E. at 546)).

91 See H. Henn \& J. Alexander, supra note 8, §§ 235, 240. 
ration. ${ }^{92}$ Meinhard presents significant problems in this context when the conflict involves necessary business and distributional decisions, such as the employment of personnel and the payment of dividends, which, given the organization's structure, inevitably will involve benefit to the fiduciary as well as the beneficiary.

When a close corporation pays a dividend or redeems stock, the distribution will accrue to the benefit of controlling shareholders as well as minority shareholders. ${ }^{93}$ When the corporation employs a controlling shareholder for a salary, she will receive a benefit which may not be available to all shareholders. The decisions made may well have different, and sometimes adverse, effects on different shareholders. For example, the tax effect of a particular distribution might be more adverse to one shareholder than to another, or the opportunity to obtain a salary from the corporation may be distributed unequally. The Meinhard principle cannot simply require the disclosure of such transactions, since the minority shareholders will be powerless to change the outcome or otherwise protect themselves. ${ }^{94}$

In order to be effective in close corporations, the Meinhard principle must require more than a duty of disclosure. But what? Does application of the broad Meinhard principle require that controlling shareholders of close corporations must, in such instances, subjugate their own interests to those of the other shareholders? And how is

92 See J.C. SHEPHERD, supra note 1, at 366-67.

93 As the cases show, sometimes distributions accrue only to the benefit of controlling shareholders. See, e.g., Alaska Plastics, Inc. v. Coppock, 621 P.2d 270, 277 (Alaska 1980) (finding that "director's fees" beyond the reasonable value of services rendered may be constructive dividends resulting in a benefit to the majority stockholder without a corresponding benefit to the minority). Another possibility is that "in a corporation with a single class of shares, the control shareholder possibly could recapitalize and reorganize the corporation by creating a new class of shares with dividend preferences, and issuing the new class to himself. Thereafter, the control shareholder could pay dividends only to the shares with preference." Comment, Valuing Closely Held Stock: Control Premiums and Minority Discounts, 31 EMORY L.J. 139, 162 n.90 (1983).

94 Cf. Goldberg v. Meridor, 567 F.2d 209, $218-20$ (2d. Cir. 1977) (holding that failure by directors to disclose their alleged breach of fiduciary duty was actionable under $\S 10$ (b) of the Securities Exchange Act of 1934 since disclosure would have enabled plaintiff shareholders to bring an action to enjoin the alleged breach), cert. denied, 434 U.S. 1069 (1978).

Disclosure and approval by the minority would provide meaningful protection, but this solution might give too great a measure of control to the minority. Cf. Smith v. Atlantic Properties, Inc., 12 Mass. App. Ct. 201, 207-09, 422 N.E.2d 798, 802-03 (1981) (discussed infra notes 154.64 and accompanying text). Disclosure and approval requirements also present the problem of identifying those business decisions that would require such ratification. 
the problem resolved when all of the shareholders have a measure of control? How is each to discharge her fiduciary duty to the others? The answer given by contemporary courts appears to be that this fiduciary duty is discharged simply by avoiding blatant and intentional unfairness to the minority. Although courts generally describe this duty as one of fairness ${ }^{95}$ or utmost good faith and loyalty, ${ }^{96}$ the analysis employed and results achieved are quite different from those in traditional fiduciary analysis. ${ }^{97}$ As an examination of the cases shows, the courts are increasingly abandoning application of fiduciary principles with respect to close corporations.

\section{B. The Dilemma of Fiduciary Duty in Close Corporations: An Irrepressible Conflict}

A good starting point for analyzing the recent jurisprudence of fiduciary duty in the close corporation context is the famous Massachusetts trilogy, Donahue v. Rodd Electrotype Co., ${ }^{98}$ Wilkes v. Springside Nursing Home, Inc., ${ }^{99}$ and Smith v. Atlantic Properties, Inc. ${ }^{100}$ These cases, occurring within a period of only six years, illustrate the first

95 See, e.g., Harman v. Masoneilan Int'l, Inc., 442 A.2d 487, 492 (Del. 1982) (concluding that a majority shareholder occupies a fiduciary relationship to minority shareholders "from which springs a duty of fairness"); Alpert v. 28 Williams St. Corp., 63 N.Y.2d 557, 569, 473 N.E.2d 19, 26, 483 N.Y.S.2d 667, 674 (1984) (transaction viewed as a whole must be fair to minority shareholders).

96 See, e.g., Burt v. Irvine Co., 237 Cal. App. 2d 828, 850, 47 Cal. Rptr. 392, 406 (1965) (holding that majority owes to minority shareholders "a duty of highest good faith"); Weinberger v. UOP, Inc., 457 A.2d 701, 710 (Del. 1983) (concluding that those in control of the corporation must demonstrate "their utmost good faith"); Lirosi v. Elkins, 89 A.D.2d 903, 906, 453 N.Y.S.2d 718, 722 (1982) (stating that a majority shareholder owes the minority shareholder "a duty of the utmost good faith").

97 Cf. Afterman, Statutory Protection for Oppressed Minority Shareholders: A Model for Reform, 55 VA. L. REv. 1043, 1061 (1969) ("Good faith' under section 210 [of the English Companies Act, dealing with oppression,] apparently stresses concepts of impropriety and overreaching which are analogous, if not identical to, the notion of fairness.").

98367 Mass. 578, 328 N.E.2d 505 (1975). For a good analysis of Massachusetts case law preceding Donahue, see Note, Contractual Disclaimer of the Donahue Fiduciary Duty: The Efficacy of the Anti-Donahue Clause, 26 B.C.L. Rev. 1215, 1218-22 (1985). See also Recent Development, 61 CoRnell L. Rev. 986, 997-1008 (1976) (discussing fiduciary duty in close corporations before and after Donahue).

99370 Mass. 842,353 N.E.2d 657 (1976).

10012 Mass. App. Ct. 201, 422 N.E.2d 798 (1981). Smith is an appeals court decision and therefore of less precedential value than Donahue and Wilkes. Although the Supreme Judicial Court has not expressly affirmed Smith, its discussion of that case in Zimmerman v. Bogoff, 402 Mass. 650, 657-58, 524 N.E.2d 849, 853-54 (1988), without critical comment, is consistent with my view, see infra text preceding note 164, that Smith is a correct application of Wilkes and Donahue. 
two stages of close corporation fiduciary analysis. Each of the cases deals with the controlling group's alleged breach of its fiduciary duty ${ }^{101}$ to the powerless shareholder as a result of corporate action or inaction traditionally within the sole discretion of the board of directors. Each case standis for the proposition that, regardless of the capacity of the persons owing the duty, the duty is owed to the shareholders (although whether it is owed in addition to, or instead of, to the corporation, is unclear). ${ }^{102}$ Ultimately, from the relatively modest beginnings of Donahue, the cases work a radical change in the philosophy and function of fiduciary analysis in the close corporation context.

In Donahue, the Supreme Judicial Court of Massachusetts adopted the broad principle of Meinhard as the fiduciary standard applicable to shareholders of close corporations. ${ }^{103}$ Donahue involved a challenge to Rodd Electrotype's repurchase of a majority of the shares of Harry Rodd, its retiring director, president, and former controlling shareholder, leaving the corporation in the management of Rodd's children who, as a group, controlled a majority of the

101 The cases often fail to identify clearly the capacity of the person owing the duty, in other words, whether the duty is owed by a director, officer, or shareholder. See, e.g., Chiles v. Robertson, 94 Or. App. 604, 627, 767 P.2d 903, 916 (1989) (stating that "[d]istinctions between the cluties of directors and the duties of controlling shareholders are simply irrelevant"); J.C. SHEPHERD, supra note 1, at $366 \mathrm{n} .87$ ("In the closely held company, these roles [director, officer, and shareholder] are simply irrelevant."). Distinguishing among these roles is not particularly important because of the lack of separation of ownership and control in close corporations. The distinction is significant, however, for determining whether the action is properly brought in the name of the complaining shareholder or as a derivative suit.

102 Again the distinction may be important for determining the form of the action. See supra note 101. For cases holding that directors and/or controlling shareholders in close corporations owe a fiduciary duty to the minority shareholders, see Jones v. Ahmanson, 1 Cal. 3d 93, 108, 460 P.2d 464, 471, 81 Cal. Rptr. 592, 599 (1969) ("Majority shareholders may not use their power to control corporate activities to benefit themselves alone or in a manner detrimental to the minority."); Comolli v. Comolli, 241 Ga. 471, 475, 246 S.E.2d 278, 281 (1978) (stating that majority shareholders owe a fiduciary duty to minority); Cookies Food Products, Inc. v. Lakes Warehouse Distributing, Inc., 430 N.W.2d 447, 451 (Iowa 1988) (same). But see Grant v. Winstead, 476 So. $2 d$ 36, 40 (Ala. 1985) (stating that there is no fiduciary duty owed by a director, officer, or shareholder to another director/shareholder when the latter is in a position to protect her own interests adequately); Ingle v. Glamore Motor Sales, Inc., 73 N.Y.2d 183, 189, 535 N.E.2d 1311, 1314, 538 N.Y.S.2d 771, 774 (1989) (stating that no "duty of loyalty and good faith" precludes termination by a controlling shareholder of a close corporation of a shareholder's employment with the corporation).

103 See Donahue, 367 Mass. at 594-95, 328 N.E.2d at 516. 
corporation's stock. ${ }^{104}$ Euphemia Donahue sued to rescind the repurchase, ${ }^{105}$ alleging that the action breached the directors' fiduciary duty to her ${ }^{106}$ since she was not accorded an "equal opportunity to sell her shares to the corporation."107

Perhaps the most significant aspect of the court's holding is its conclusion "that stockholders in the close corporation owe one another substantially the same fiduciary duty in the operation of the enterprise that partners owe to one another."108 The court described this duty as one of " "utmost good faith and loyalty," which means that such stockholders "may not act out of avarice, expediency or self-interest in derogation of their duty of loyalty to the other stockholders and to the corporation."109 As later cases demonstrate, the difficult problem is determining when a fiduciary's self-interested actions are "in derogation of [her] duty of loyalty."

The court imposed this duty due to the fiduciary characteristics of the intra-corporate relationship. ${ }^{110}$ But the court also implicitly recognized the controlling shareholders' legitimate interests in the corporate property and the problem of restricting shareholder fiduciaries too severely in their ability to benefit from these interests:

We stress that the strict fiduciary duty which we apply to stockholders in a close corporation ... governs only their actions relative to the operations of the enterprise and the effects of that operation on the rights and investments of other stockholders. We express no

104 Rodd gave the balance of his shares as gifts to his children. See id. at 582 , 328 N.E.2d at 510.

105 See id. at 584, 328 N.E.2d at 511.

106 See id. at $579,585,328$ N.E.2d at $508,511$.

107 Id. at 585,328 N.E.2d at 511.

108 Id. at 593,328 N.E. 2 d at 515.

109 Id. (quoting Cardullo v. Landau, 329 Mass. 5, 8, 105 N.E.2d 843, 845 (1952)). An interesting and difficult problem presented by this case is the court's failure to identify the fiduciary beyond the control group generally. Although this is not a problem in Donahue, where the members of the control group were related and appeared to share common interests, it is difficult to determine when this group fiduciary concept is to be applied to less cohesive control groups. See infra note 132 and accompanying text; see also Recent Development, supra note 98, at 1015 (discussing the definition of a community interest).

110 See Donahue, 367 Mass. at 586-93, 328 N.E.2d at 512-15. For a discussion of these characteristics, see supra notes $24-46$ and accompanying text. These characteristics include the reliance of each of the stockholders on the others' "fidelity and abilities," Donahue, 367 Mass. at 587, 328 N.E.2d at 512; see also J.C. SHePherd, supra note 1, at 56-60 (discussing reliance theory of fiduciary duty), the minority's vulnerability to oppressive action by the majority, see Donahue, 367 Mass. at 588-92, 328 N.E.2d at 513-14; Frankel, supra note 1, at 809-16 (focusing on abuse of power), and the difficulties of proof faced by the minority in establishing self-serving conduct, see Donahue, 367 Mass. at 589-90, 328 N.E.2d at 513-14. 
opinion as to the standard of duty applicable to transactions in the shares of the close corporation when the corporation is not a party to the transaction. ${ }^{111}$

Unfortunately, while the court seemed to recognize the problem of inherent conflicts of interest., it failed to recognize the reality of close corporations: the substantial congruity of corporate actions with the actions of controlling shareholders. It also failed to indicate the limits, if any, of this strict fiduciary duty. ${ }^{112}$

The difficulty with the court's failure fully to appreciate the realities of close corporations becomes clear upon analysis of its holding: "We hold that, in any case in which the controlling stockholders have exercised their power over the corporation to deny the minority such equal opportunity [to sell their shares to the corporation], the minority shall be entitled to appropriate relief." 113 This rule is simple, clear, apparently easy to apply, and seems to fit the facts of the case. But when combined with the realities of close corporations, the rule's difficulties become obvious. In the first place, although clearly consistent with Meinhard, it goes beyond the duty of disclosure imposed in that case by requiring equality in the opportunity of shareholders to benefit from the use of corporate property. Of course, imposition of a requirement of disclosure would be meaningless in Donahue. In Meinhard, Salmon's disclosure of the opportunity would have given Meinhard the chance to compete for it. Mrs. Donahue, however, as a minority shareholder, had no power to alter the challenged transaction. The equal opportunity rule is consistent with the principles of Meinhard by, in effect, eliminating the disparity in power by mandating the opportunity to participate. ${ }^{114}$ Unlike the

111 Id. at 593 n.18, 328 N.E.2d at 515 n.18.

112 This reality, however, was appreciated by Judge Wilkins's concurrence. See id. at 604, 328 N.E.2d at 521 (Wilkins, J., concurring); see also Dynan v. Fritz, 400 Mass. 230, 242 n.17, 508 N.E.2d 1371, 1378 n.17 (1987) (indicating that the Donahue duty, which it incorrectly characterized as a "duty of care," did not necessarily apply in a derivative action "where the alleged wrong sought to be redressed is to the corporation ... and not to some portion of the stockholders, [although] [t] the two concepts tend to merge . . . when a shareholder's alleged self-aggrandizement, if true, hurts both the corporation and the interests of the other stockholders"). In Bessette v. Bessette, 385 Mass. 806, 434 N.E.2d 206 (1982), in which minority shareholders sought to recover excessive salary payments to controlling shareholders, the Massachusetts Superior Court distinguished Donahue by holding that, where the relief sought properly accrued to the corporation (as in Bessette), the proper method of recovery was through a derivative suit. See id. at 808-09, 434 N.E.2d at 207-08.

113 Donahue, 367 Mass. at 600, 328 N.E.2d at 519.

114 Cf Brudney, Fiduciary Ideology, supra note 1 , at $261 \mathrm{n} .7$ (noting the two methods of implementing fiduciary restrictions: categorical denial and offsetting the 
situation in Meinhard, however, the action of the power holder in Donahue had utility beyond the simple gratification of the power holder's selfish interest. And therein lies the problem.

Not every corporate repurchase of stock would so clearly evidence self-dealing on the part of the control group as (arguably) did the repurchase in Donahue. ${ }^{115}$ Clearly legitimate business purposes may be served by encouraging or facilitating the retirement of an officer or director who offers no further utility to the corporation, or who simply wants to retire and has no further interest in the corporation's activities. Given the nature of close corporations and the typicality of a shareholder's large investment of personal wealth in the corporation, ${ }^{116}$ it is likely that such a shareholder would need her capital returned in order to fund her retirement, and that the ultimate best interests of the business would be to return her capital. ${ }^{117}$ Application of the equal opportunity rule in Donahue to all corporate repurchases, however, would make every retirement of a controlling shareholder the opportunity for effective dissolution. ${ }^{18}$ It is difficult to imagine this result serving the best interests of the enterprise. So the problem of identifying the circumstances in which the unequal distribution of corporate assets would be consistent with fiduciary duty, of defining "loyal inequality" as it were, continues to exist. ${ }^{119}$

fiduciary's "advantages of position"); Hetherington, The Minority's Duty of Loyalty in Close Corporations, 1972 DUKE L.J. 921, 946 [hereinafter Hetherington, Duty of Loyalty] (stating that "[l]oyalty is . . . the surrogate for control").

115 For example, in Leader v. Hycor, Inc., 395 Mass. 215, 479 N.E.2d 173 (1985), the Supreme Judicial Court upheld the recapitalization of a corporation by its control group for the purpose of eliminating public minority shareholders. It should be noted that the lower court decision affirmed by the Supreme Judicial Court treated the corporation as a close corporation, despite the presence of public shareholders, a distinction the Supreme Judicial Court found unnecessary to address. See id. at 222, 479 N.E.2d at 177. On the other hand, in Dynan v. Fritz, 400 Mass. $230,244,508$ N.E.2d 1371, 1379 (1987), a derivative action in which the court held that an agreement between the corporation and its controlling shareholder to repurchase that shareholder's shares at a price dictated by the controlling shareholder and approved by a fully interested board was voidable by the corporation unless a majority of the disinterested shareholders approved the transaction. Cf. Toner v. Baltimore Envelope Co., 304 Md. 256, 263, 498 A.2d 642, 646 (1985) (declining to apply a per se prohibition to selective stock repurchases by a close corporation).

116 See supra note 4.

117 See, e.g., Toner, 304 Md. at 276, 498 A.2d at 652 (discussing circumstances under which such a stock repurchase might be in the best interests of the company).

118 See Recent Development, supra note 98, at 1012.

119 Easterbrook and Fischel are highly critical of the court's failure to appreciate the propriety of the repurchase in Donahue, suggesting that it did not take into account the reasons for fiduciary duties, which they believe to be providing a low transaction cost on the basis of contractual terms for which the parties would have. 
Neither the rule nor the broader opinion resolves this question. In fact, the opinion later casts doubt on whether unequal distribution of corporate assets is per se a breach of fiduciary duty. ${ }^{120}$ Massachusetts law denied preemptive rights to stockholders unless provided in the charter or a shareholder-adopted by-law. Since the repurchase obligation established by the court is the functional inverse of preemptive rights, the court evidently felt the need to deal with this issue: ${ }^{121}$

We do not here suggest that such preemptive rights are required by the strict fiduciary duty applicable to the stockholders of close corporations. However, to the extent that a controlling stockholder or other stockholder, in violation of his fiduciary duty, causes the corporation to issue stock in order to expand his holdings or to dilute holdings of other stockholders, the other stockholders will have a right to relief in court. ${ }^{122}$

This is curious. It suggests that an essential aspect of the breach of fiduciary duty is the increased concentration of power by the controlling stockholder. It is also illogical since the controlling stockholder already, by definition, controls the corporation. ${ }^{123}$ To the extent

negotiated had they done so. See Easterbrook \& Fischel, supra note 83, at 294-95. As I explain in Part III, I believe that it is Easterbrook and Fischel who fail to understand the reasons for fiduciary duties. Ste infra notes 215-42 and accompanying text.

120 See Donahue, 367 Mass. at 600 n.25, 328 N.E.2d at 519 n.25.

121 It is not clear why the court dealt with this issue as there was no change in the identity of the control group nor was there any potential change in Mrs. Donahue's pro rata share of the corporation's earnings or assets. See Donahue v. Rodd Electrotype Co. of New England, Inc., 1 Mass. App. Ct. 876, 876, 307 N.E.2d 8, 9 (1974) (noting no "significant change in the ultimate control of the corporation"), rev'd, 367 Mass. 578, 328 N.E.2d 505 (1975).

122 Donahue, 367 Mass. at 600 n.25, 328 N.E.2d at 519 n.25 (emphasis added); see also Ski Roundtop, Inc. v. Hall, 202 Mont. 260, 276-81, 658 P.2d 1071, 1080-83 (1983) (holding that disproportionate purchases of stock by a controlling shareholder from the corporation to obtain and maintain control were not in breach of his fiduciary duty when the result of his control was demonstrably beneficial to the corporation).

123 See Dynan v. Fritz, 400 Mass. 230, 236-37, 508 N.E.2d 1371, 1375 (1987) (reversing a lower court holding that certain sales of stock by the corporation to defendants were improper when one of the defendants already was, and remained, in control of the corporation); see also Toner v. Baltimore Envelope Co., 304 Md. 256, 275, 498 A.2d 642, 651-52 (1985) (holding that the corporation's repurchase of stock which increased the controlling shareholder's voting interest from $50 \%$ to $51 \%$ could not have injured minority stcckholder); Baker v. Standard Lime \& Stone Co., 203 Md. 270, 284, 100 A.2d 82?, 829 (1953) (affirming dismissal of minority stockholder challenge to corporation's purchase of its own shares, on the grounds that the resulting change in control was not adverse to the minority's interests because "[t]hey lost no voting power by the transaction . . . [since they] were and remain minority stockholders"). 
that the breach of fiduciary duty consists of the controlling stockholder's increase in her pro rata share of the corporation's earnings and assets, ${ }^{124}$ it is irrelevant to the case since no such increase occurred there. ${ }^{125}$ Although selective issuances of stock could result in such an increase, the footnote states that such a concentration or dilution is grounds for relief only if undertaken in breach of a fiduciary duty. 126

This formulation is problematic for two reasons. First, it calls into question the scope of the court's equal opportunity rule. Perhaps not every corporate action that disproportionately affects shareholders is a per se breach of fiduciary duty. Second, it leaves unanswered the question of when such a breach of fiduciary duty has occurred. ${ }^{127}$ The explanation for the logical defects in Donahue is that fiduciary analysis is not necessarily logical, nor is it intended to be. Rather, its purpose is, in part, to express and, when necessary, to enforce community norms regarding the ethical standards of business conduct. ${ }^{128}$ But Donahue still leaves unanswered the question of the parameters of those norms.

The question of when a breach of fiduciary duty has occurred is answered in Wilkes $v$. Springside Nursing Home, Inc. ${ }^{129}$ a case which

124 As a matter of finance theory, the use of corporate funds to effect the repurchase, a fact which obviously troubled the court, caused no harm to Mrs. Donahue. See infra note 145 and accompanying text; see also Herbik v. Rand, 732 S.W.2d 232, 234-35 (Mo. Ct. App. 1987) (issuance of shares by corporation at less than alleged fair market value was not oppressive conduct under Missouri statute where preemptive rights of each shareholder were protected and there was no showing that the minority shareholders were unable to purchase their pro rata share).

125 Cf. Toner, $304 \mathrm{Md}$. at 275, $498 \mathrm{~A} .2 \mathrm{~d}$ at 652 (minority shareholder's interest was not injured by corporation's repurchase of stock because her stock was nonvoting and that purchase increased the value of her interest upon liquidation).

126 See Donahue, 367 Mass. at 600 n.25, 328 N.E.2d at 519 n.25; see also Ski Roundtop, Inc. v. Hall, 202 Mont. 260, 658 P.2d 1071 (1983).

127 It may be that such a breach occurs only when corporate assets are used, which would be consistent with the holding and facts in Donahue. But this is not likely to be the case in new share issuances. Conversely, in many cases of disproportionate treatment, such as employment, it will always be the case that corporate assets are used. But see Forinash v. Daugherty, 697 S.W.2d 294, 304-05 (Mo. Ct. App. 1985) (finding, despite the non-use of corporate assets, a breach of fiduciary duty by the officers and directors of a close corporation when they sold their non-controlling shares to one individual, thus creating a controlling shareholder, who subsequently mismanaged the corporation).

128 See, e.g., B. CARDozo, supra note 82, at 43-50 (discussing the limits of logic in judicial reasoning).

129370 Mass. 842, 353 N.E.2d 657 (1976). The method of analysis in Wilkes was also adopted in a New York case decided contemporaneously with Donahue. See Schwartz v. Marien, 37 N.Y.2d 487, 335 N.E.2d 334, 373 N.Y.S.2d 122 (1975). 
exemplifies the second stage of fiduciary analysis in close corporations. Four shareholders (including Wilkes) owned an equal number of shares in Springside Nursing Home, Inc. For a number of years, the four served as the corporation's directors and officers, and received an equal salary for their services. After a falling-out with one of the shareholders, Wilkes was denied a place on the board as well as corporate employment (and, consequently, his salary) in contravention of an arrangement followed from the time of incorporation. ${ }^{130}$ Wilkes sued for declaratory judgment establishing breach by the other three shareholders of an alleged partnership agreement or, alternatively, of their fiduciary duties to him as controlling shareholders. ${ }^{131}$

As in Donahue, the court treated the group of shareholders opposed to Wilkes as "the fiduciary," based upon their aggregate control of the corporation. Following Donahue's concern with the potential in close corporations for the majority to deny the minority any financial benefits, realized in this case by the denial of employment and salary to Wilkes, the court held that the "group fiduciary" owed a duty to Wilkes, a duty it had breached. ${ }^{132}$

The relationship appears to be fiduciary in nature, for the same reasons discussed in Donahue. The corporation was an aspect of Wilkes's economic life. The three controlling shareholders, assuming a commonality of interest, were charged with its conduct, exclusive of Wilkes. Thus the power holder/dependent relationship clearly existed. But again, the power holder had a legitimate selfinterest in the aspect of the dependent's life over which it held sway. And the facts in Wilkes, dealing as they do with the ordinary business decision of corporate employment, present a much clearer dilemma than did Meinhard and Donahue, which arguably involved, respectively, the taking and selective distribution of corporate property. The existence of an intractable and legitimate conflict of interest hampers the analysis of the fiduciary's performance and complicates analysis of the fiduciary's motives.

Obviously, the decision to employ an individual is a business

130 See Wilkes, 370 Mass. at $844-48,353$ N.E.2d at $659-61$. It is noteworthy that the corporation never declared or paid a dividend. See id. at 850 n.13, 353 N.E.2d at 662 n.13.

131 See id. at $843-44,353$ N.E.2d at 659 . Not the least interesting aspect of this case is the way the court treated as irrelevant the distinction between corporate and partnership law. See id. at 848,353 N.E.2d at 661 . Such treatment gave the case a decidedly contractual tint.

132 See id. at $852-53,353$ N.E.2d at 664. 
decision generally entrusted to a corporation's board of directors. ${ }^{133}$ Equally obviously, it cannot always be a breach of fiduciary duty, even in a close corporation, to refuse or cease to employ a particular shareholder in the business, ${ }^{134}$ just as the court in Donahue seemed to recognize that it cannot always be a breach of fiduciary duty selectively to repurchase a shareholder's stock. ${ }^{135}$ The problem is compounded in the close corporation context by the court's implicit recognition that such a "corporation" in reality has no interest of its own apart from that of the individual shareholders, each of whom will expect some benefit from the corporation that may be inconsistent with the benefits expected by other shareholders. ${ }^{136}$ As the Wilkes court put it: "The majority, concededly, have certain rights to what has been termed 'selfish ownership' in the corporation which should be balanced against the concept of their fiduciary obligation to the minority." 137

So how can a court determine that the action of one group of shareholders to benefit themselves is a breach of fiduciary duty to the minority? The answer, according to Wilkes, depends upon "whether the controlling group can demonstrate a legitimate business purpose

133 See, e.g., Ali Principles of Corporate Governance $\$ \S 3.01,3.02$ (Tent. Draft No. 2 1984).

134 See, e.g., Streb v. Abramson-Caro Clinic, 401 So. 2d 410, 414 (La. Ct. App.) (holding a minority shareholder's allegations insufficient to establish breach of fiduciary duty where majority shareholder terminated minority shareholder's employment), cert. denied, 403 So. $2 d 69$ (La. 1981); Harris v. Marden Business Sys., Inc., 421 N.W.2d 350, 354 (Minn. Ct. App. 1988) (holding that majority shareholder in close corporation owes no fiduciary duty to employees, even if employees are minority shareholders in the corporation, and thus there is no breach of fiduciary duty when majority shareholder fires employee for legitimate business purpose); Exadaktilos v. Cinnaminson Realty Co., Inc., 167 N.J. Super. 141, 155-56, 400 A.2d 554, 561-62 (1979) (finding no breach of fiduciary duty where close corporation terminated minority shareholder's employment because of unsatisfactory performance), aff'd, 173 N.J. Super. 559, 414 A.2d 994, cert. denied, 85 N.J. 112, 425 A.2d 273 (1980); Ingle v. Glamore Motor Sales, Inc., 73 N.Y.2d 183, 188-90, 535 N.E.2d 1311, 1313-14, 538 N.Y.S.2d 771, 773-74 (1989) (finding no breach of fiduciary duty when majority shareholders of a close corporation terminated the employment of a minority shareholder whose employment was not governed by an express agreement of duration or conditions of employment).

135 See supra note 117-19 and accompanying text; see also Toner v. Baltimore Envelope Co., 304 Md. 256, 498 A.2d 642 (1985); $ø$. Unocal Corp. v. Mesa Petroleum Co., 493 A.2d 946, 956-58 (Del. 1985) (permitting selective repurchases of stock by corporation as part of a tender offer defense).

136 Cf. Mitchell, supra note 58 , at $479-80$ (noting that in close corporations, individual shareholders attempt to realize their personal goals through the enterprise, and those goals may be inconsistent with the goals of the close corporation as a whole).

137 Wilkes, 370 Mass. at 850-51, 353 N.E.2d at 663 (citations omitted). 
for its action."138 If such a purpose is demonstrated, the challenged action presumptively is not a breach of fiduciary duty, unless the minority can "demonstrate that the same legitimate objective could have been achieved through an alternative course of action less harmful to the minority's interests."139 In Wilkes, the majority demonstrated no legitimate business purpose. Consequently, the court held that the majority breached its fiduciary duty. ${ }^{140}$

This is a truly remarkable transformation of fiduciary doctrine. In Donahue, the Massachusetts Supreme Judicial Court adopted as the fiduciary standard governing close corporation shareholders the lofty aspirations of Judge Cardozo and the New York Court of Appeals in Meinhard $v$. Salmon. ${ }^{141}$ I have already noted the alogical, unyielding nature of the fiduciary standard seemingly articulated in Donahue. Yet only fifteen months later, in Wilkes, the same court announced that this unyielding principle would indeed yield against the press of the fiduciary's business goals. Strikingly, the court held that not only would the principle yield, but further that whether any breach of fiduciary duty had occurred was to be analyzed by means of a balancing test.

The concept of balancing is wholly inconsistent with the broad notion of fiduciary duty and its expression in Meinhard and Donahue. ${ }^{142}$ Balancing provides a complete shift in focus from the classic fiduciary examination of whether the action taken was in the beneficiary's best interests to a mode of analysis that centers on the fiduciary's interest. Thus, fiduciary conduct is now analyzed by examining whether the fiduciary had a motive other than to harm the benefici-

198 Id. at 851,353 N.E.2d at 663 (citations omitted).

$139 \mathrm{Id}$. at 851-52, 353 N.E.2d at 663 (citations omitted).

140 See id. at 852,353 N.E.2d at 663 (observing that "it is apparent that the majority stockholders in Springside have not shown a legitimate business purpose").

141 See supra text preceding note 103.

142 See Brudney, Fiduciary Ideology, supra note 1, at 270 ("Strict fiduciary considerations would make any ... legitimate business purpose irrelevant ...."). But see Hetherington, Defining the Scope, supra note 9, at 13, 14 (limits to fiduciary duty "are the working out of a balancing of interests among the participants in corporate enterprises").

The only apparent consequence of establishing a fiduciary relationship in Wilkes is the shifting of the burden of proof to the fiduciary. Of course, the proof that the fiduciary must offer is not of selfless devotion, or even fairness, but simply of a business purpose, which should generally be easy to establish. Once this purpose is established, the burden of proof shifts back to the dependent. Thus, the real issue is going to be the legitimacy of the majority's business purpose, an inquiry courts are quite reluctant to undertake. 
ary, rather than whether the fiduciary acted in the beneficiary's best interest. ${ }^{143}$

In reality, the Wilkes rule is not so stark as this. Rather, it shifts the burden from the fiduciary who has demonstrated a legitimate business purpose to the beneficiary who, to prevail, must then demonstrate that the majority could have achieved its business goal through methods less harmful to the beneficiary. This approach could exact a price in efficiency by requiring controlling interests to structure transactions in a more expensive manner to avoid harm to the minority. But it is consistent with traditional corporate governance principles, rather than strict fiduciary principles, in that it implicitly equates the best interests of the minority with the best interests of the corporation, as determined by the majority. ${ }^{144}$ The Wilkes rule returned the resolution of close corporation disputes largely to a power struggle between majority and minority, with the minority inevitably losing absent some evidence that the majority completely disregarded or intentionally damaged the minority's interests. In so doing, it set the groundwork for the third stage of development of fiduciary analysis.

I do not mean to suggest that the problem is a simple one, or that the Massachusetts court was irrational in designing its solution. But the difficulty of resolving these conflicts by application of the Wilkes test can be demonstrated by applying that test to the facts of Donahue, and then to a hypothetical problem based upon the facts of Wilkes.

In Donahue, a clearly legitimate business purpose existed: the smooth and uneventful retirement of Harry Rodd. As indicated in my discussion of that case, it is reasonable to assume that Rodd needed his capital returned in order to finance his retirement, or at least that he was unhappy with the prospect of leaving a substantial portion of his wealth invested in a business over which he desired to exercise no further control. The most (if not only) effective way to achieve this was to have either the corporation or the remaining shareholders purchase his shares. If the latter course were pursued (which it wasn't), the purchasing shareholders would have had to use their own capital, but the net effect (financial and in terms of control) on Mrs. Donahue would have been no less harmful than if the corpo-

143 Cf. Hillman, supra note 19 , at 45 (noting that the "traditional" definition of oppression focuses more on the actions of the majority than on the impact on the minority).

144 Chittur has pointed out the ease with which a defendant could justify a given transaction in terms of legitimate business interests. See Chittur, supra note 54, at 153. 
ration had engaged in the repurchase. ${ }^{145}$ So, while a purchase by the controlling shareholders would have had the simple advantage of avoiding the use of corporate funds, it would ultimately have been inconsequential to the minority. The only less intrusive means to accomplish that business purpose would have been to provide Mrs. Donahue the opportunity to purchase a pro rata portion of Harry's shares, and the cases cited by the Donahue court support this remedy. ${ }^{146}$ Thus, application of the Wilkes test to Donahue seems to produce the same result, which is consistent with the reasoning in Donahue and its reliance on Meinhard v. Salmon.

What, however, would be the result in Wilkes if the termination of Wilkes had been found to have a legitimate business purpose? Assume, for example, that Wilkes had a specialized skill, for example masonry, which was no longer needed by the corporation, and that Wilkes possessed no skills which could be used profitably by the corporation. Assume further that the corporation was having financial difficulties such that it could not pay dividends. Could the directors, consistent with their fiduciary duties, terminate Wilkes's employment?

The answer must be yes. But both the question and the answer pose an interesting dilemma, highlighted by the apparent focus of the Wilkes court on the fiduciary duty of the control group as shareholders rather than as directors. ${ }^{147}$ As directors and controlling shareholders, the defendants have a duty to the corporation. Consistent with that duty, Wilkes's employment would have to be termi-

145 This is true, at least theoretically, because the diminution in outstanding shares that actually occurred in Donahue concentrated the earnings to be distributed among a fewer number of shares. Of course this also assumes that the expenditure of corporate funds on the repurchase did not diminish the corporation's earning capacity and that the repurchase itself was a good investment for the corporation. See Recent Development, supra note 98, at 1008-09 (discussing the equal opportunity doctrine whereby all shareholders must be afforded the opportunity to participate in stock repurchases); see also Frantz Mfg. Co. v. EAC Indus., 501 A.2d 401 (Del. Ch. 1985) (applying a similar analysis).

146 See, e.g., Jones v. Ahmanson, I Cal. 3d 93, 109-10, 460 P.2d 464, 472-73, 81 Cal. Rptr. 592, 600-01 (1969) (holding that controlling shareholders have a fiduciary duty when dealing in their shares). It should be noted that this remedy actually would have resulted in an improvement in Mrs. Rodd's position as against the fiduciary group, whereas a purchase of Harry's shares solely by the fiduciary group would have left the relative positions of Mrs. Rodd and the fiduciary group unchanged.

147 Compare Wilkes, 370 Mass. at 851-52, 353 N.E.2d at 663 with Forinash v. Daugherty, 697 S.W.2d 294, 304 (Mo. Ct. App. 1985) (in discussing their fiduciary duties, focusing on the roles of members of the control group as officers and directors of the corporation). 
nated. As directors and controlling shareholders, however, defendants also owe a direct fiduciary duty to Wilkes. ${ }^{148}$ It might be inconsistent with that duty to terminate Wilkes's employment, and thus his salary, particularly without any prospect of dividends in sight. ${ }^{149}$

The situation is further complicated if we assume that, in addition to the four controlling shareholders, additional non-director minority shareholders exist. In that case, not only will the controlling shareholders have a duty to treat Wilkes fairly, but as directors they will have a clearer independent duty to the remaining shareholders to terminate Wilkes's employment. Fulfilling their duty to Wilkes might well result in breaching their duty to the remaining shareholders. ${ }^{150}$

Applying the principles of Donahue to this case, each member of the control group would have to agree to a pro rata diminution in salary in order to create a fund to be used to maintain Wilkes's salary at a level equal to theirs in accordance with their original understanding and long term business practices. This agreement would enable the control group to fulfill its fiduciary duty to Wilkes without imposing additional costs on the business. ${ }^{151}$ This appears to be a

148 See 68th St. Apts., Inc. v. Lauricella, 142 N.J. Super. 546, 557, 362 A.2d 78, 84 (1976) ("It would thus be vain to attempt to distinguish acts done as shareholders from those done as directors, or to distinguish a principal's duty to serve the corporation as director from his right to protect his personal interest as stockholder."), aff'd, 150 N.J. Super. 47, 374 A.2d 1222 (1977). But see Harris v. Mardan Business Sys., Inc., 421 N.W.2d 350, 353 (Minn. Ct. App. 1988) (distinguishing between controlling person's capacity as an employer and as a shareholder); Ingle v. Glamore Motor Sales Inc., 73 N.Y.2d 183, 188-90, 535 N.E.2d $1311,1313-14,538$ N.Y.S.2d 771, 773-75 (1989) (same); Solomon v. Atlantis Dev., Inc., 147 Vt. 349, 354-57, 516 A.2d 132, 135-37 (1986) (applying Massachusetts law, distinguishing between defendant's vote as a director and as a stockholder, and holding that, since he voted in the latter capacity and since he satisfied the Wilkes test, there was no breach of fiduciary duty).

149 See, e.g., Zidell v. Zidell, Inc., 277 Or. 423, 430, 560 P.2d 1091, 1094 (1977) ("We do not believe ... that the protective approach taken in [Donahue] would require the corporation to tailor its policies to favor a minority shareholder at the expense of the majority." (citing Wilkes, 370 Mass. at 851-52, 353 N.E.2d at 663)). It should be noted that Zidell was a derivative action and thus the question was detriment to the corporation rather than to the minority shareholder.

150 Cf. Comolli v. Comolli, 241 Ga. 471, 475, 246 S.E.2d 278, 281 (1978) ("Directors may decide in good faith what is best for the corporation, but this interest must be consistent with good faith to the minority stockholder."). In this case, after the complained-of corporate action was taken, the only two shareholders of the corporation were plaintiff and defendant, so in fact, the director's notion of the corporation's best interest was arguably identical to his own best interest. See id. at 471-72, 246 S.E.2d at 279.

151 Easterbrook and Fischel agree that this is the logical implication of Donahue. 
ridiculous resolution, at least when the members of the control group provide necessary services to the corporation. But it is the consequence of imposing a strict fiduciary duty upon individuals who necessarily have conflicts of interest which may very well clash at some point during the course of their relationship. ${ }^{152}$

These analytical difficulties call into question the utility of fiduciary duty in the close corporation context. ${ }^{153}$ The analysis is particularly troublesome in the context of transactions involving areas of conduct not directly relating to the directors as shareholders. Donahue, involving a stock repurchase from a controlling shareholder with corporate funds, was more clearly a self-dealing case than Wilkes, which involved (at least superficially) hiring and termination decisions traditionally within the province of the board. Smith v. Atlantic Properties, Inc. ${ }^{154}$ the third case in the trilogy, also involved an area exclusively within board discretion, the payment of dividends ${ }^{155}$ and the making of capital improvements. Smith suggests that the difficulty lies not with the application of strict fiduciary principles in close corporations but with the logical consequences of bending these principles to ameliorate their harshness.

Smith, like Wilkes, involved a corporation in which four shareholders owned equal numbers of shares. At the time of incorpora-

See Easterbrook \& Fischel, supra note 83, at 295; cf. Balvik v. Sylvester, 411 N.W.2d 383,388 (N.D. 1987) (termination of the minority shareholder's employment by the majority shareholder constituted "oppressive" conduct within the meaning of North Dakota's forced dissolution statute, "whether Sylvester discharged Balvik from employment for cause" or as retaliation for instituting the lawsuit). In contrast, another court explained:

Fiduciary duties cannot require the perpetration of highway robbery, nor can they require the fiduciary to make a gift to the beneficiary .... [A] breach of a corporate fiduciary duty simply allows the minority to get the most that it could have obtained in the absence of the breach. It does not guarantee the minority a windfall.

Chiles v. Robertson, 94 Or. App. 604, 628, 767 P.2d 903, 916 (1989).

This might also be the result of applying Dean O'Neal's reasonable expectations analysis and possibly even Professor Hillman's modification of that approach, each of which is discussed in Part III. See infra notes 225-32 and accompanying text.

152 The absence of less harmful corporate means to achieve the goal of terminating Wilkes does not mitigate the harm to him as a shareholder. fiduciaries.

153 And, of course, the policy of treating close corporation shareholders as

15412 Mass. App. Ct. 201, 422 N.E.2d 798 (1981).

155 See Dodge v. Ford Motor Co., 204 Mich. 459, 170 N.W. 668 (1919). But see Fox v. 7L Bar Ranch Co., 198 Mont. 201, 212, 645 P.2d 929, 934 (1982) (" '[T]he logic which supports judicial reluctance to interfere with dividend policies in large corporations does not apply to close corporations.' " (quoting Manne, Our Two Corporation Systems: Law and Economics, 53 VA. L. REv. 259, 280 (1967))). 
tion, however, plaintiff (who was also a lawyer), included in the charter and by-laws a provision requiring that all significant corporate actions be approved by 80 percent of the voting stock (the " 80 percent provision"), effectively providing a veto power to each shareholder. ${ }^{156}$ For most of the corporation's existence, Dr. Wolfson, one of the shareholders, disagreed with his colleagues over the payment of dividends. ${ }^{157}$ Dr. Wolfson (who not coincidentally was in a high tax bracket) preferred that the business retain all earnings, for the stated purpose of making capital improvements to the corporation's property, and consequently vetoed the payment of any dividends. The remaining shareholders, desiring dividends, refused to accede to these capital improvement plans. ${ }^{158}$ This stalemate resulted in penalty tax assessments against the corporation by the Internal Revenue Service. ${ }^{159}$ Ultimately, the other shareholders sued Dr. Wolfson seeking a determination of dividends to be paid by the corporation, the removal of Dr. Wolfson as a director and reimbursement of the corporation from Wolfson for the penalty taxes. ${ }^{160}$

Based on a footnote in Donahue, the Smith court found that although Wolfson was in fact a minority shareholder, the 80 percent provision effectively gave him (and every other shareholder) control of the corporation. Consequently, the court imposed on Dr. Wolfson the controlling shareholder's fiduciary duty established in Donahue. ${ }^{161}$ Again, however, the fiduciary faced the problem of legitimate conflicting interests, and the Smith court's articulation of the Wilkes test amply reveals its recognition of this problem. In affirming the trial court's imposition of liability on Wolfson for breach of his fiduciary duty, the appeals court applied the Wilkes test as follows:

The most pertinent guidance is probably found in the Wilkes case $\ldots$, essentially to the effect that in any judicial intervention in such a situation there must be a weighing of the business interests advanced as reasons for their action (a) by the majority or controlling group and (b) by the rival persons or group. ${ }^{162}$

Although this formulation is different from that used in Wilkes, the court correctly expressed the underlying principle of that case in the context of a corporation in which, in any given transaction, each of

156 See Smith, 12 Mass. App. Ct. at 202, 422 N.E.2d at 799.

$157 \mathrm{Dr}$. Wolfson had requested inclusion of the $80 \%$ provision. See id.

158 See id. at 203, 422 N.E.2d at 800.

159 See id.

160 See id. at 204,422 N.E.2d at 800.

161 See id. at 206-07, 422 N.E.2d at 802.

162 See id. at 208, 422 N.E.2d at 802 (emphasis added and citations omitted). 
the shareholders could be deemed to be a controlling shareholdercontrolling shareholders have the right to "selfish ownership." That right is balanced against the fiduciary duties they owe to other shareholders. The exercise of selfish ownership by the controlling group is not a breach of fiduciary duty as long as the controlling group has a "better" business purpose than does the non-control group. Given the traditional corporate law principle that corporate decisions are to be made by the majority (of directors or shareholders), ${ }^{163}$ the effect of the Smith analysis is to eliminate the concept of fiduciary duty in close corporations by permitting the majority's "better" business purpose to override the interests of the minority. Although the analysis remains within the rhetorical framework of fiduciary duty, the ultimate rule of Smith is that the court will uphold a corporate transaction made by directors who are controlling shareholders where all of the directors are interested so long as a business purpose superior to that desired by the minority can be demonstrated. In short, the court simply threw up its hands when faced with a situation in which conflict appeared irrepressible, and left the conflict to be resolved in a simple power struggle. ${ }^{164}$

Although the Massachusetts Supreme Judicial Court started with the high moral principles expressed in Meinhard, when it began to modify those principles to resolve the practical problems arising in their application to close corporations, the principles ceased to have analytical utility in resolving legal disputes. The court's solution was not to restore those principles but to shift the analytical focus from the beneficiary's interest to the fiduciary's conduct, and to leave the initial determination of the propriety of that conduct in the hands of the fiduciary. The fiduciary is permitted to balance her own selfinterest against the interests of the beneficiary. To this balancing, courts typically will defer.

\section{The Tort of "Freeze-Out" and the Action for Oppression: Fiduciary Duty Transformed}

States that have identified the existence of a fiduciary relation-

163 See Comolli v. Comolli, 241 Ga. 471, 475, 246 S.E.2d 278, 281 (1978).

164 Although this is the clear result of the court's legal analysis, as a practical matter, it didn't abandon fiduciary principles quite so starkly. Rather, it retained jurisdiction over the case to ensure balanced conduct by both sides, see Smith, 12 Mass. App. Ct. at 210-11, 422 N.E.2d at 804, in a sense balancing their fiduciary obligations. As I will discuss in the Conclusion, I believe that this mutual imposition of fiduciary duties should be incorporated into legal doctrines as the most appropriate solution to the problem. See infra note 243 and accompanying text. 
ship among close corporation shareholders ${ }^{165}$ have transformed the standard of "utmost good faith and loyalty" announced in Donahue v. Rodd Electrotype Co. ${ }^{166}$ The resulting third stage of fiduciary development in close corporations is a doctrine unrecognizable as fiduciary duty, although still couched in that rhetoric. For the most part, courts have abandoned the assumptions and philosophy underlying fiduciary duty when confronted with the logical implications of the fiduciary's and beneficiary's common ownership of assets within the close corporate structure. They have moved from the conclusion that selfless conduct is both possible and a social good, to the easier pragmatic solution of permitting self-interested conduct in the absence of the fiduciary's malfeasance.

This change has also resulted in a shift in the function of fiduciary duty, from a broad moral precept designed to encourage corporate cohesion to a remedial tool providing relief to complaining shareholders upon proof of the majority's bad conduct. Courts claiming to apply fiduciary principles to close corporations find breach of fiduciary duty only when controlling interests have abused their position and intentionally excluded minority shareholders from corporate benefits. The resulting doctrine, although applied under the rubric of fiduciary duty, does not rest upon the philosophy underlying fiduciary principles, but instead resembles intentional tort. Rather than demand that the fiduciary protect the best interests of the beneficiary, courts now require, in actions denominated the common law tort of freeze-out ${ }^{167}$ and the statutory remedy for

165 See, e.g., Orchard v. Covelli, 590 F. Supp. 1548, 1558 (W.D. Pa. 1984) (finding breach of fiduciary duty where majority shareholder engaged in "systematic effort" to deny minority shareholder benefits from the corporation); Comolli v. Comolli, 241 Ga. 471, 474-75, 246 S.E.2d 278, 280-81 (1978) (majority shareholder in close corporation who had corporation purchase shares of its own stock in order to "depreciate[]" minority interest, "render him ineffective and 'freeze' his investment" breaches duty of good faith); 68th St. Apts., Inc., v. Lauricella, 142 N.J.Super. 546, 563,362 A.2d 78, 88 (1976) (finding breach of duty of good faith where coventurer in closed corporation unjustifiably terminated the relationship in violation of the agreement); In re Gene Barry One Hour Photo Process, Inc., 111 Misc. 2d 559, 565, 444 N.Y.S.2d 540, 544 (Sup. Ct. 1981) (citing Wilkes to same effect as Donahue with respect to scope of fiduciary duty in interpreting New York dissolution statute).

166367 Mass. 578, 593, 328 N.E.2d 505, 515 (1975).

167 See, e.g., Sugarman v. Sugarman, 797 F.2d 3, 7-8 (1st Cir. 1986) (setting forth test minority shareholders must meet to establish a freeze-out claim); Orchard $v$. Covelli, 590 F. Supp. 1548, 1557 (W.D. Pa. 1984) (stating that attempts to "squeeze out" minority shareholders constitute a breach of fiduciary duty); Masinter $v$. WEBCO Co., 164 W. Va. 241, 251-56, 262 S.E.2d 433, 440-42 (1980) (upholding the minority shareholder's claim of freeze-out); $c f$. Denihan v. Denihan, 119 A.D.2d 144, $147-50,506$ N.Y.S.2d 39, 41-43 (1986) (granting an injunction of corporate 
oppression, ${ }^{168}$ only that the fiduciary not actively seek to harm the beneficiary.

Although cases following Donahue describe the scope of fiduciary duty in terms of good faith and fairness, they actually analyze alleged breaches in terms of bad faith and wrongful conduct rather than the fiduciary's failure to pursue selflessly the beneficiary's interests. ${ }^{169}$ Many cases following Wilkes concede that legitimate business reasons for the complained-of conduct would immunize the controlling interests from liability, even though the conduct resulted in harm to the beneficiary or disproportionate benefit to the fiduciary. ${ }^{170}$ The

transaction which minority shareholder claimed was designed to squeeze him out of the corporation, pending arbitration pursuant to a stockholders' agreement).

168 Although the remedy for oppression has a statutory basis in most states, at least two jurisdictions have a judicially created remedy for oppression. See Forinash v. Daugherty, 697 S.W.2d 294, 305 (Mo. Ct. App. 1985); Masinter v. WEBCO Co., 164 W. Va. 241, 252, 262 S.E.2d 433, 440 (1980).

The meaning of the term "oppression," while articulated in a variety of ways, appears to be relatively consistent among jurisdictions, and seems to require proof that the majority has abused its position or taken unfair advantage of the minority. See, e.g., Gidwitz v. Lanzit Corrugated Box Co., 20 Ill. 2d 208, 214, 220, 170 N.E.2d $131,135,138$ (1960) (finding cumulative effects of improper conduct to be oppressive); Kisner v. Coffey, 418 So. 2d 58, 61 (Miss. 1982) (holding that an abuse of corporate position for private gain is oppressive conduct). Some jurisdictions provide an approach less dependent upon abuse or wrongful activity than upon analysis focused on the expectations of the beneficiary. See, e.g., Fox v. 7L Bar Ranch Co., 198 Mont. 201, 209-10, 645 P.2d 929, 933-34 (1982) (defining oppression in terms of reasonable expectations of minority shareholders); In re Kemp \& Beatley, Inc., 64 N.Y.2d 63, 73, 473 N.E..2d 1173, 1179, 484 N.Y.S.2d 799, 805 (1984) (holding that the use of reasonable expectations "as a means of identifying and measuring conduct alleged to be oppressive is appropriate"); see also Afterman, supra note 97, at 1063 (noting that "oppression can be defined in terms of the reasonable expectations of the minority shareholders"); Hillman, supra note 19, at 38-55 (noting that oppression can "be defined in terms of reasonable expectations of the minority shareholders in the particular circumstances").

Part III of this Article argues that this "expectations" approach is also a departure from fiduciary principles. See infra notes 225-32 and accompanying text.

169 See, e.g., Galbreath v. Scolt, 433 So. 2d 454, 457 (Ala. 1983) (noting that a cause of action may exist where majority shareholders "deprive" the minority shareholders of their share of corporate gains); Comolli v. Comolli, 241 Ga. 471, 475,246 S.E.2d 278, 281 (1978) (noting that directors' actions taken to "freeze" minority shareholder's investment demonstrates a "lack of good faith" and may be a breach of fiduciary duty); Estate of Schroer v. Stamco Supply, Inc., 19 Ohio App. 3d $34,39,482$ N.E.2d 975, 980 (1984) (referring to a majority shareholder's duty to not "misuse power" by furthering personal interests at the expense of the corporation).

170 See, e.g., Cookies Food Prod., Inc. v. Lakes Warehouse Distrib., Inc., 430 N.W.2d 447, 453 (Iowa 1988) (finding that self dealing is permissible if corporate directors can demonstrate "good faith, honesty and fairness"); Streb v. AbramsonCaro Clinic, 401 So. 2d 410, 414 (La. Ct. App.) (concluding that removal of a minority shareholder from the board of directors does not necessarily constitute a breach of fiduciary duty), cert. denied, 403 So. 2d 69 (La. 1981); Toner v. Baltimore 
clear import is that actions of controlling interests in close corporations will not result in liability so long as those actions are not intended to harm the minority shareholders. This reduces fiduciary analysis to nothing more than the avoidance of unfair treatment of the minority, rather than exclusive pursuit of the minority's interests. Perhaps the clearest articulation of this approach is Zidell $v$. Zidell, Inc.: $:^{171}$

"If there are plausible business reasons supportive of the decision of the board of directors, and such reasons can be given credence, a Court will not interfere with a corporate board's right to make that decision .... It is our duty to redress wrongs, not to settle competitive business interests. Absent any bad faith, fraud, breach of fiduciary duty or abuse of discretion, no wrong cognizable by or correctable in the courts has occurred."172

This, of course, is nothing more than a restatement of the business judgment rule and leaves open the question of what constitutes a breach of fiduciary duty or, in the language of the courts following Donahue and Wilkes, what constitutes unfairness.

The answer, as suggested above, is that unfair conduct consists of action taken to benefit the controlling interests at the expense of the minority interests, with no independent legitimate business purpose. Alternatively, unfair conduct may exist where there is some other showing of intentional wrongdoing. Thus in Leader v. Hycor, Inc., ${ }^{173}$ the Massachusetts court held that a recapitalization plan designed to eliminate minority shareholders had a legitimate business purpose and did not violate the majority shareholder's fiduciary duty. ${ }^{174}$ On the other hand, courts have found unfairness where

Envelope Co., 304 Md. 256, 273, 498 A.2d 642, 650, (1985) (observing that determinations of breach of fiduciary duty must be made by considering all relevant facts and focusing on the business setting and purpose of the act when the alleged breach occurred); Harris v. Marden Business Sys., Inc., 421 N.W.2d 350, 353 (Minn: Ct. App. 1988) (finding no breach of fiduciary duty when majority shareholder terminates minority shareholder's employment for a legitimate business reason); Exadaktilos v. Cinnaminson Realty Co., 167 N.J. Super. 141, 155-56, 400 A.2d 554, 561-62 (Law Div. 1979) (no breach of fiduciary duty when close corporation terminated minority shareholder's employment because of unsatisfactory performance), aff'd, 173 N.J. Super. 559, 414 A.2d 994, cert. denied, 85 N.J. 112, 425 A.2d 273 (1980).

171277 Or. 413, 560 P.2d 1086 (1977).

172 Id. at 419,560 P.2d at 1089 (quoting Gay v. Gay's Super Markets, Inc., 343 A.2d 577, 580 (Me. 1975)) (emphasis deleted and added). In support of this proposition the court cited Wilkes, among other cases. See id.

173395 Mass. 215, 479 N.E.2d 173 (1985).

174 See id. at 222, 479 N.E.2d at 177; see also Horizon House-Microwave, Inc. v. Bazzy, 21 Mass. App. Ct. 190, 198-200, 486 N.E.2d 70, 76-77 (1985) (holding that a 
directors and officers, through the sale of their shares, have created a single controlling shareholder where none had previously existed, even where legitimate business purposes were present. ${ }^{175}$ Courts have also held the payment of preferential dividends ${ }^{176}$ and selective redemptions ${ }^{177}$ to be unfair.

The cases demonstrate that isolated action taken by controlling interests which harms minority shareholders, or which disproportionately benefits majority shareholders, is not by itself a breach of fiduciary duty. In addition, courts require that there be evidence of intentional wrongful conduct towards the minority shareholders, designed to deprive the minority of corporate benefits. Lack of legitimate business purpose for an action or a consistent pattern of selfdealing or minority harm is evidence of such conduct. ${ }^{178}$ This mode of analysis, of course, is entirely inconsistent with the notion of fiduciary duty expressed in Meinhard and Donahue.

Few of the cases following Donahue base a finding of a breach of fiduciary duty on a single business action, such as a corporate repurchase of stock or excessive salary payments. Rather, in each case, a pattern of conduct has led the court to conclude that the intent of the majority was either to eliminate the minority from the corporation or

triangular merger, cashing out a minority shareholder, over his objection, while providing stock in the surviving entity to the majority shareholder, had the legitimate business purpose of quelling corporate dissent); Solomon v. Atlantis Dev., Inc., 147 Vt. 349, 356, 516 A.2d 132, 136 (1986) (applying Massachusetts law and holding that the sale of corporate assets to a corporation owned by a controlling shareholder was not a breach of fiduciary duty where a legitimate business purpose existed). But see Bodio v. Ellis, 401 Mass. 1, 8-11, 513 N.E.2d 684, 688-89 (1987) (holding that on the facts of the case, the majority interests of a closely held corporation had a duty to maintain the balance of corporate control).

175 See Forinash v. Daugherty, 697 S.W.2d 294, 302-07 (Mo. 1985).

176 See Tillis v. United Parts, Inc., 395 So. 2d 618, 619 (Fla. Dist. Ct. App. 1981);

Anderson v. Clemens Mobile Homes, Inc., 214 Neb. 283, 287-88, 333 N.W.2d 900, 903-04 (1983).

177 See Comolli v. Comolli, 24:1 Ga. 471, 474-76, 246 S.E.2d 278, 280-82 (1978);

Estate of Schroer v. Stamco Supply, Inc., 19 Ohio App. 3d 34, 482 N.E.2d 975 (1984).

178 Cf. Baker v. Commercial Body Builders, Inc., 264 Or. 614, 630, 507 P.2d

387, 394 (1973). The Oregon Supreme Court explained that a

single act in breach of sucls a fiduciary duty may not constitute such 'oppressive' conduct as to authorize the dissolution of a corporation unless extremely serious in nature and that even a continuing course of 'oppressive' conduct may not be sufficient for that purpose unless it appears that, as a result, there has been a disproportionate loss to the minority or that those in control of the corporation are so incorrigible that they can no longer be trusted to manage it fairly in the interests of its stockholders.

Id. (footnotes omitted). 
to deny it all corporate benefit. Thus, in Donahue, the facts revealed not only a selective repurchase, but the offer by the corporation to repurchase Mrs. Donahue's shares at an inadequate price, ${ }^{179}$ and the consolidation of shares in the hands of a control group, composed of members of the same family with a presumed commonality of interests. ${ }^{180}$ In Wilkes, not only was Wilkes's employment terminated, but the corporation had never paid dividends ${ }^{181}$ and Wilkes was stripped of his place on the board of directors. ${ }^{182}$ The requirement of a pattern of actions has become a fixture in the $\operatorname{cases}^{183}$ and has culminated in the development of the "tort of freeze-out."

The tort of freeze-out receives its most cogent expręssion in the First Gircuit case of Sugarman v. Sugarman. ${ }^{184}$ The case involved a family corporation originally founded by four brothers and ultimately controlled by Leonard Sugarman, the son of one of the founders and the holder of a majority of the corporation's stock. The plaintiffs, descendants of the other founding brothers, owned the balance of the other shares. ${ }^{185}$ In 1981 , the plaintiffs sued Leonard both derivatively and individually. In the individual count, they pleaded "the theory of 'freeze-out' of minority shareholders,"186 alleging that Leonard had deprived them of desired employment with the corporation, paid himself excessive compensation which "drained-off" the company's earnings, and refused to pay dividends. ${ }^{187}$

The court, affirming the district court's judgment on the freezeout theory, analyzed Massachusetts precedent to determine the elements of the cause of action:

179 See Donahue, 367 Mass. at 584 n.10, 328 N.E.2d at 511 n.10.

180 See id. at 601,328 N.E.2d at 519.

181 See Wilkes, 370 Mass. at 850 n.13, 353 N.E.2d at 662 n.13.

182 See id. at 847,353 N.E.2d at 661 .

183 See, e.g., Orchard v. Covelli, 590 F. Supp. 1548 (W.D. Pa. 1984), aff'd, 802 F.2d 448 (3d Cir. 1986). In discussing the systematic "freeze-out" of a minority shareholder by the majority, the Orchard court observed that similar patterns often occur in close corporations:

Tolstoi once wrote that "happy families are all alike; every unhappy family is unhappy in its own way." We sense that Tolstoi was less familiar with the American modern law of closely-held corporations from which we note an alarming similarity in the demise of such entities where the survival of a business association is so perilously tied to the continuing vitality of intimate personal relationships.

Id. at 1550 .

184797 F.2d 3 (1st Cir. 1986).

185 See id. at 6.

$186 \mathrm{Id}$.

187 See id. 
In these cases, the [Supreme Judicial Court] has pioneered in developing an effective cause of action for minority shareholders who have been denied their fair share of benefits in close corporations. At the same time, it has carefully set out the contours of that cause of action. First, it is not sufficient for a minority shareholder to prove that the majority shareholder has taken excessive compensation or other payments from the corporation....

Second, it is not sufficient to allege that the majority shareholder has offered to buy the stock of a minority shareholder at an inadequate price....

[In order to establish the cause of action,] the minority shareholder must first establish that the majority shareholder employed various devices to ensure that the minority shareholder is frozen out of any financial benefits from the corporation through such means as the receipt of dividends or employment, and that the offer to buy stock at a low price is the "capstone of the majority plan" to freeze-out the minority. ${ }^{188}$

Thus the key to the theory of freeze-out is the occurrence of a series of actions designed to deny minority shareholders all financial benefits from the corporation: The activity is tortious, ${ }^{189}$ the tort must be intentional, and the deprivation must be purposeful. ${ }^{190}$ This, of course, is quite different from the traditional twin duties of a fiduciary to act in the beneficiary's best interests and to avoid self-dealing.

Masinter $v$. WEBCO Co. ${ }^{191}$ illustrates the increasing tendency of courts to view actions for breach of fiduciary duty in terms of bad faith and wrongful conduct. Masinter also demonstrates the similarity between the theory of freeze-out and the other common approach, the action for oppression, as well as the equation of both of these theories with fiduciary duty. In Masinter, two of three equal shareholders were allied against the third as a result of a falling out. ${ }^{192}$ They voted to remove plaintiff from the board of directors and to terminate him as corporate secretary, thereby depriving him of his salary. ${ }^{193}$ In addition, they caused the corporation to enter into a new loan agreement (to which the plaintiff had objected) restricting, among other things, the payment of dividends.

In reversing the lower court's grant of summary judgment

188 Id. at 7-8 (emphasis added and citations omitted).

189 See id. at 14; see also Mack v. American Nat'l Bank, 510 N.E.2d 725, 738-39 (Ind. App. 1987) (noting the trend to label breaches of fiduciary duty as torts and surveying precedent to that effect).

190 See Sugarman, 797 F.2d at 8.

191164 W. Va 241, 262 S.E.2d 433 (1980).

192 See id. at 245-46, 262 S.E.2d at 437.

193 See id. 
against plaintiff, the court recognized an action for oppression notwithstanding the lack of a statutory basis in West Virginia at the time of the facts giving rise to the complaint. ${ }^{194}$ Furthermore, the court identified the attempt to freeze-out a minority shareholder as one type of oppressive conduct. ${ }^{195}$ Ultimately, the court equated oppressive conduct with breach of fiduciary duty in the context of close corporations. ${ }^{196}$ In articulating the standard for oppressive conduct/breach of fiduciary duty, ${ }^{197}$ the court looked to the definition expressed by the Oregon Supreme Court in Baker v. Commercial Body Builders, Inc.: 198

" 'burdensome, harsh and wrongful conduct; a lack of probity and fair dealing in the affairs of a company to the prejudice of its members; or a visual [sic] departure from the standards of fair dealing, and a violation of fair play on which every shareholder who entrusts his money to a company is entitled to rely." "199

More specifically, Masinter noted that the freeze-out of a minority shareholder consists of "depriving him, without any legitimate business purpose, of any benefit from his ownership and investment in a corporation." 200

This cause of action is dramatically different from the action for breach of fiduciary duty enunciated in Meinhard and Donahue and rests upon completely different principles. In those cases, wrongful-

194 See id. at 245-48, 262 S.E.2d at 437-38. By the time of the suit, the West Virginia legislature had adopted such a cause of action. See id. at 252 n.11, 262 S.E.2d at 440 n.I1.

195 See id. at 251-54, 262 S.E.2d at 440-41; see also Exadaktilos v. Cinnaminson Realty Co., 167 N.J. Super. 141, 154, 400 A.2d 554, 561 (1979) (declaring freezeouts an abuse of corporate power prohibited by a New Jersey statute forbidding oppressive conduct in close corporations), aff'd, 173 N.J. Super. 559, 414 A.2d 994, cert. denied, 85 N.J. 112, 425 A.2d 273 (1980).

196 See Masinter, 164 W. Va. at 251, 262 S.E.2d at 440. The court discussed cases from other jurisdictions concerning oppressive conduct as a statutory remedy and determined that the West Virginia standard for breach of fiduciary duty was equivalent to the standard that other courts had developed for oppressive conduct. See id.; see also Afterman, supra note 97, at 1060-61 (suggesting that the prohibition of oppression in an English corporation statute may be analogized to a breach of fiduciary duty); Macdonald, supra note 19, at 171 ("Courts began to acknowledge that if the controlling shareholders breached their fiduciary duty to the minority shareholders, oppression resulted.").

197 See Masinter, 164 W. Va. at 251-52, 262 S.E.2d at 440.

198264 Or. 614, 507 P.2d 387 (1973).

$199 \mathrm{Id}$. at 628-29, 507 P.2d at 393 (quoting Comment, Oppression as a Statutory Ground for Corporate Dissolution, 1965 DukE L.J. 128, 134 (footnotes omitted)). The word misquoted by the Oregon Supreme Court is "visible." See Comment, supra, at 134.

200 See Masinter, 164 W. Va. at 251-54, 262 S.E.2d at 440-41. 
ness and intent were irrelevant: all that mattered was unequal treatment and the disloyalty of the fiduciary in the sense of failing to further the beneficiary's best interests. The current approach is to disregard loyalty entirely and to eliminate unequal treatment as a per se violation, in favor of an evaluation of the intent and wrongfulness of the majority's conduct. The result is judicial recognition of selfinterested conduct as a legitimate form of business behavior. It is not an analysis premised on fiduciary duty at all.

A recent decision by the New York Court of Appeals further demonstrates the trend away from fiduciary analysis and the increasing primacy (if not exclusivity) of intent based actions. In Ingle $v$. Glamore Motor Sales, ${ }^{201}$ Ingle had become an employee of the defendant corporation when Glamore, the then sole shareholder, refused to sell him an equity interest in the corporation. Glamore subsequently sold a portion of his shares to Ingle, who became a director and secretary of the corporation. ${ }^{202}$ As part of the agreement with Glamore, Ingle gave Glamore the right to purchase his stock if the corporation ceased to employ him for any reason. Although the initial agreement was later terminated, this provision remained in all subsequent agreements to which Ingle was a party. ${ }^{203}$

Almost twenty years after Ingle's initial employment, the Board of Directors fired him and terminated his corporate positions. At the time of his termination, Ingle owned twenty-five percent of the corporation's shares (at one point he had owned forty percent). ${ }^{204}$ Glamore informed Ingle that he was exercising his repurchase option. Ingle sued, alleging that although he was an employee atwill, Glamore's fiduciary duty as majority shareholder precluded Glamore from terminating Ingle and triggering the repurchase option. ${ }^{205}$

The court rejected this argument out of hand, affirming the dismissal of the complaint on the ground that Ingle's employment relationship was governed by New York's employment at-will doctrine, not by any protection he might have as a minority shareholder. ${ }^{206}$ The court went further:

Ingle's and the dissent's reliance on Fender $v$. Prescott . . . for an

20173 N.Y.2d 183, 535 N.E.2d 1311, 538 N.Y.S.2d 771 (1989).

202 See id. at 186,535 N.E.2d at 1312,538 N.Y.S.2d at 772.

203 See id. at $186-87,535$ N.E.2d at 1312,538 N.Y.S.2d at 772.

204 See id. at 191, 535 N.E.S.d at 1315, 538 N.Y.S.2d at 775 (Hancock, J., dissenting).

205 See id. at $187-88,535$ N.E.2d at $1312-13,538$ N.Y.S.2d at 773.

206 See id. at 188, 535 N.E.2d at 1313, 538 N.Y.S.2d at 773. 
exception based on the close corporate form in which this employer and employee find themselves is unavailing. No duty of loyalty and good faith akin to that between partners, precluding termination except for cause, arises among those operating a business in the corporate form who "have only the rights, duties and obligations of stockholders' and not those of partners. ${ }^{207}$

In support, the court cited a 1957 case, Weisman v. Awnair Corp., ${ }^{208}$ in which the court of appeals affirmed the dismissal of a complaint by a shareholder alleging breach of fiduciary duty on the ground that what the plaintiff really was alleging was the conduct of a joint venture through the corporate form, which was impermissible. Unlike joint venturers, held the court, corporate shareholders have no fiduciary duty towards one another. ${ }^{209}$ Thus Ingle stands for the proposition that, under New York law, shareholders in a corporation, close or otherwise, are not bound by fiduciary duties. ${ }^{210}$

Unfortunately the opinion's logic is difficult to discern, and Judge Bellacosa's bifurcation of the relationship into employer/ employee and majority shareholder/minority shareholder is unduly formalistic and unrealistic. But the truly interesting and significant aspect of the opinion is that the plaintiff was not left completely without remedy. Rather, the court stated: "We have no occasion to address issues involved in cases where the minority shareholders may be discharged solely to avoid assertion of the legal rights afforded to them under [the New York] Business Corporation Law .... because no such matter has been pleaded and that is not this case."211 The rights referred to by the court are the statutory right of a minority shareholder to bring an action to dissolve the corporation because of oppressive conduct by the majority, and the majority's correlative right to buy-out the minority's interest. ${ }^{212}$ Ingle

207 Id. at 189,535 N.E.2d at 1314,538 N.Y.S.2d at 774 (citations omitted) (quoting Weisman v. Awnair Corp., 3 N.Y.2d 444, 449-50, 144 N.E.2d 415, 418, 165 N.Y.S.2d 745, 750 (1957)).

2083 N.Y.2d 444, 144 N.E.2d 415, 165 N.Y.S.2d 745 (1957).

209 See id. at 450,144 N.E.2d at 418,165 N.Y.S.2d at 750.

210 Although the court expressly reserved the issue of shareholders' fiduciary duties in Ingle, in Gallagher v. Lambert, 74 N.Y.2d 562, 549 N.E.2d 136, 549 N.Y.S.2d 945 (1989), the court confirmed explicitly that no fiduciary duty among shareholders precluded a majority shareholder from terminating the employment of a minority shareholder to take advantage of a low repurchase price triggered by the firing under a shareholder's agreement.

211 Ingle, 73 N.Y.2d at 189,535 N.E.2d at 1314,538 N.Y.S.2d at 774.

212 See N.Y. Bus. CoRP. LAw §§ 1104-a, 1118 (McKinney 1986 \& Supp. 1990); see also In re Pace Photographers, 71 N.Y.2d 737, 744-45, 525 N.E.2d 713, 716, 530 N.Y.S.2d 67, 70 (1988) (discussing the origins and operation of $\S \S 1104-\mathrm{a}$ and 1118 ). In In re Kemp \& Beatley, Inc., 64 N.Y.2d 63, 473 N.E.2d 1173, 484 N.Y.S.2d 799 
suggests that the statutory remedy, at least when it applies, is exclusive in New York, and that outside of that context no remedy for fiduciary breaches by controlling shareholders exists. ${ }^{213}$ Ingle thus illustrates the overt replacement of fiduciary principles with the theory underlying the oppression action.

\section{Fiduciary Duty and Fiduciary Rights}

A number of commentators have suggested ways of analyzing fiduciary duty in close corporations to account for the problems I have described. In general, these proposals, while occasionally evident in the case law, ${ }^{214}$ are more sophisticated than the tests devel-

(1984), the court defined "oppression" in terms of the denial of the complaining shareholder's reasonable expectations. See id. at 73, 473 N.E.2d at 1179,484 N.Y.S.2d at 805. In Part III of this Article, I explain why the reasonable expectations test is a departure from fiduciary cluty. See infra text accompanying notes 225-32.

213 Ingle has the limited virtue: of being more straightforward than many of the oppression cases in dealing with the relationship between fiduciary duty and oppression. Other courts, however, have reached similar conclusions. See, e.g., Jordan v. Bowman Apple Products Co., Inc., 728 F. Supp. 409 (W.D. Va. 1990) (holding that the statutory oppression remedy in Virginia superseded common law rights of action for oppression and limited plaintiff's remedies to those available under the statute). But see In re Denihan, 119 A.D.2d 144, 149-50, 506 N.Y.S.2d 39, 43 (1986) (enjoining corporate transaction that minority claimed was designed to squeeze him out of the corporation pending arbitration pursuant to stockholders' agreement).

214 See, e.g., Jordan v. Duff \& Phelps, Inc., 815 F.2d 429, 437 (7th Cir. 1987) (applying hypothetical bargaining approach), cert. dismissed, 108 S. Ct. 1067 (1988); Notzke v. Art Gallery, Inc., 84 Ill. App. 3d 294, 298-99, 405 N.E.2d 839, 842-43 (1980) (finding defendants conduct "overbearing and heavy-handed" thus meeting the statutory requirement of oppressive conduct as interpreted in the case law); Capitol Toyota, Inc., v. Gervin, 381 So. 2d 1038, 1039-40 (Miss. 1980) (reversing "involuntary dissolution on the statutory ground of 'oppression' where the complaining party's reasonable expectations [had] been thwarted, but not grossly so"); Fox v. 7L Bar Ranch Co., 198 Mont. 201, 208-10, 645 P.2d 929, 933-34 (1982) (finding defendant's actions constituted a violation of plaintiff's "reasonable expectations as a shareholder" and thus supported dissolution); Exadaktilos v. Cinnaminson Realty Co., 167 N.J. Super. 141, 150-56, 400 A.2d 554, 559-62 (1979) (stating that the "circumstances under which the parties' expectations . . . were disappointed do not establish oppressive action"), aff'd, 173 N.J. Super. 559, 414 A.2d 994, cert. denied, 85 N.J. 112, 425 A.2d 273 (1980); McCauley v. Tom McCauley \& Son, Inc., 104 N.M. 523, 527-32, 724 P.2d 232, 236-41 (Ct. App. 1986) (reviewing lower court's finding of oppressive conduct); In re Kemp \& Beatley, 64 N.Y.2d 63, 73, 473 N.E.2d 1173, 1179, 484 N.Y.S.2d 799, 805 (1984) (holding that "utilizing a complaining shareholder's 'reasonable expectations' as a means of identifying and measuring conduct alleged to be oppressive is appropriate"); Topper v. Park Sheraton, 107 Misc. 2d 25, 33-35, 433 N.Y.S.2d 359, 356-66 (Sup. Ct. 1980) (applying implied contract analysis); Meiselman v. Meiselman, 309 N.C. 279, 299, 307 S.E.2d 551, 563 (1983) (evaluating the parties' conduct in terms "not only of the 'expectations generated by the participants' original business bargain,' but also of the 
oped by courts. ${ }^{215}$ While these approaches may differ in their particulars, the increasing equation or replacement of fiduciary analysis with analysis under statutory provisions or theories of intentional tort suggests that at the heart of the debate is the purpose to be served by fiduciary analysis and its underlying social vision. The debate really is about the way we, as a society, believe that people can and should conduct themselves in business relationships and the extent to which we are willing to use the law to encourage and, if necessary, compel them to conform to that level of conduct.

Judge Easterbrook and Professor Fischel propose an approach as removed from fiduciary theory as the conduct-oriented approach toward which the courts have been moving: ${ }^{216}$ "Fiduciary duties serve as implicit standard terms in contractual agreements that lower the cost of contracting. Properly interpreted, fiduciary duties should approximate the bargain the parties themselves would have reached had they been able to negotiate at low cost."217 Easterbrook and Fischel readily admit the difficulty inherent in identifying the particulars of this hypothetical bargain. ${ }^{218}$ To solve the problem, they suggest that courts look to the solutions adopted by the shareholders in close corporations that have reached an express bargain with respect to the relevant issue, and apply it as law in the absence of reasons to the contrary. 219

This approach has been criticized soundly by Professors DeMott $^{220}$ and Brudney. ${ }^{221}$ The important point for purposes of this Article is that the Easterbrook/Fischel proposal is not, despite

"history of the participants relationship as expectations alter.' "(quoting O'Neal, Close Corporations: Existing Legislation and Recommended Reform, 33 Bus. LAw. 873, 888 (1978))).

215 See, e.g., Hillman, supra note 19, at 50 (noting that the "reasonable expectations approach to date has received more scholarly then [sic] judicial attention"); Macdonald, supra note 19, at 175 (noting that "only a limited number of courts have used the reasonable expectations approach"). But see cases cited supra notes 168 \& 214.

216 See Easterbrook \& Fischel, supra note 83, at 291.

217 Id.

218 See id. ("[I]t is often difficult for a court to determine how the parties would have contracted had they anticipated this contingency.").

219 See id. at 300 (arguing that courts should observe how the larger close corporations deal with issues such as handling deadlocks or repurchasing shares from retiring employees). Judge Easterbrook has implemented this hypothetical bargain approach in Jordan, $815 \mathrm{~F} .2 \mathrm{~d}$ at 436 . For a cogent and, I believe, compelling criticism of this opinion, see DeMott, supra note 1, at 882-92.

220 See DeMott, supra note 1.

221 See Brudney, Corporate Governance, supra note 1; see also Branson, supra note 11 (criticizing the "contractarian approach" generally in corporate law). 
their assertions to the contrary, in any sense fiduciary duty. It does not depend upon the existence of a fiduciary relationship, ${ }^{222}$ it does not consider the best interests of the beneficiary, and it does not require any sort of disinterested conduct by the fiduciary. It is not prophylactic but remedial in nature. Finally, it ignores the fact that, as Professor DeMott points out, fiduciary duties are often counterintentional ${ }^{223}$ and, as I noted, do not depend upon logical consistency for their efficacy. ${ }^{224}$

The underlying philosophy of the Easterbrook/Fischel proposal is, of course, the desirability of enhanced efficiency. Based on their (at least implicit) assumption that shareholders are rational utility maximizers, and their concern with both excessive transaction costs and burdening corporate flexibility, they elevate the value of efficient economic arrangements over the value of selfless conduct and the social vision it expresses. Whether or not they are correct in that view, it is important in evaluating their proposal to understand that it is a clear departure from fiduciary principles.

Dean O'Neal argues in favor of legislation directing courts to protect the reasonable expectations of close corporation shareholders, apparently as a substitute for general fiduciary duty analysis. ${ }^{225}$ Although he suggests that this approach could be implemented through interpretation of oppression statutes, ${ }^{226}$ he advocates broader legislation directing judicial relief to minority shareholders based generally on the frustration of their reasonable expectations. ${ }^{227}$ The test Dean O'NJeal envisions would take account of the reasonable expectations that "exist at the inception of the enterprise, and as they develop thereafter through a course of dealing concurred in by all of [the shareholders]. . .."228 He would, however, put "primary emphasis on expectations generated by the participants' original business bargain."229

Professor Hillman has accepted and modified the idea of an

222 See DeMott, supra note 1, at 882 (suggesting significance of fiduciary relationship to fiduciary analysis).

223 See id. at 887.

224 See supra note 128 and accompanying text; see also J.C. SHEPHERD, supra note 1 , at 3; B. CARDozo, supra note 82 , at $49-50$.

225 See O'Neal, Close Corporations: Existing Legislation and Recommended Reform, 33 Bus. LAW. 873, 885 (1978).

226 See id. at 886.

227 See id.

228 Id.

229 Id. at 888; see also Afterman, supra note 97, at 1063 (noting the particular relevance of the "original understanding of the parties" in an evaluation of subsequent actions taken by the mejority). 
action for relief based on disappointment of reasonable expectations as a supplement to relief now provided by statute or equity "for such matters as oppression, deadlock, mismanagement, and failure of corporate purposes." 230 To alleviate his concern that granting relief based solely on minority shareholders' reasonable expectations would unfairly burden the expectations of the remaining shareholders and would create corporate instability, he has proposed a threepart test. The test requires the complaining shareholder to establish:

(1) that he or she became a participant because of a substantial expectation or set of expectations known or assumed by the other participants; (2) that the prospect that the expectation will be achieved is unlikely; and (3) that the failure to achieve the expectation was in large part beyond the control of the participant. ${ }^{231}$

The relief to be accorded upon such a showing is liquidation of the complaining shareholder's investment in the manner "least disruptive to the continuation of the enterprise."232

The O'Neal and Hillman approaches, like the Easterbrook/Fischel approach, attempt to resolve the fundamental problem of fiduciary analysis in close corporations by reconciling the legitimate interests of the fiduciary with those of the beneficiary. The reasonable expectations approach is closer to fiduciary principles than the hypothetical bargain approach because of its focus on minority interests, but is also a significant departure from fiduciary analysis in its implicit attempt to develop objective zones of legitimate self-interest for the controlling participants. Like the latter approach, it appears more remedial in nature than prophylactic.

Although these proposals have real merit in resolving close corporation problems, they abandon the altruism inherent in fiduciary analysis in return for more commercially-oriented concepts of good faith and fair dealing. In light of judicial unwillingness to examine the merits of business decisions, implementation of these proposals would lead back to the current trend of examining the good or bad faith of controlling shareholders.

Professor Hetherington's suggestion that minority shareholders attempting to extract disproportional shares of the corporation's ' assets should be subject to the same duty of loyalty as controlling shareholders addresses the conflict of interest problem in the con-

230 Hillman, supra note 19 , at 77.

231 Id. at 77.

232 Id. at 81. 
text of fiduciary principles. ${ }^{233}$ He perceptively identifies the duty of loyalty as a surrogate for control, ${ }^{234}$ and argues from this that its use should be subjected to the same standards applied to the actual control possessed by the majority. ${ }^{235}$

There are, however, two difficulties with his analysis. First, he equates the duty of loyalty with standards of good faith and fairness in commercial dealings, ${ }^{236}$ an equivalence with which I disagree since the latter concepts do not require the selfless disinterestedness traditionally required of a fiduciary. The second problem is Hetherington's definition of breach of the duty of loyalty as conduct detrimental to the welfare of the enterprise, ${ }^{237}$ which arguably is the welfare of the majority. This definition of breach could again lead back to the current problem of bias in favor of the majority.

Nevertheless, in a later article co-authored with Professor Dooley which focuses on the general problem of illiquidity of close corporation stock, ${ }^{238}$ Hetherington does return at least to the effect of basic fiduciary principles (although expressly rejecting fiduciary duty as a useful remedial tool) ${ }^{239}$ by arguing in favor of a mandatory buy-out right for non-controlling shareholders of close corporations with dissolution as the ultimate remedy if the buy-out is not effected. This proposal resembles fiduciary analysis in that questions of motive and intent are eliminated, and the remedy imposed is absolute. However, fiduciary duty and selfless conduct for their own sake are not part of Hetherington and Dooley's concern. Ultimately, Hetherington rejects fiduciary analysis in favor of a contractually based expectations analysis. ${ }^{240}$ This proposal is subject to the same criticisms as the Easterbrock/Fischel, O'Neal, and Hillman proposals, and stems from Hetherington's search for a workable remedy for majority abuse. ${ }^{241}$ Again, this analysis disregards the prophylactic function of fiduciary duty and abandons any attempt to encourage high standards of business ethics.

233 See Hetherington, Duty of Loyalty, supra note 114.

234 See id. at 946.

235 See id.

236 See id. at 933.

237 See id. at 945.

238 See Hetherington \& Dooley, supra note 10.

$239 \mathrm{See}$ id. at 6 . One obvious error of this analysis is the treatment of fiduciary principles as remedial, rather as prophylactic. Of course, this form of analysis is the trend of the case law as well.

240 See Hetherington, Defining the Scope, supra note 9.

241 See id. at 21-22 (discussing failure of various remedies for dealing with the majority's exclusion of the minority from sharing economic benefits the business has generated). 
Finally, Professor Brudney advocates a return to strict fiduciary principles, at least in certain transactional contexts. ${ }^{242} \mathrm{He}$ evidently does not regard the balancing of competing interests as an issue because, at least with respect to these transactions, he sees no suffciently strong motivation (other than self-interest) which would justify considering the interests of the majority. This approach leaves no room for majority self-interest in accomplishing these transactions. He suggests, however, that the potential for abuse in close corporations is so great that, absent imperative reasons justifying these transactions, they should be flatly prohibited.

\section{ConClusion}

At the heart of fiduciary analysis is an assumption that individuals can act in a selfless manner and a desire that, for the good of society, they do so. Although the early application of fiduciary principles to close corporation participants was consistent with these ideals, the practical problems of accommodating controlling shareholders' legitimate self-interest has led courts and commentators to develop analytical approaches to fiduciary duty which depart from them. My own view is that fiduciary duty is a valuable principle and an important supplement to the remedial approaches provided by statute.

The problems it presents in close corporation law are not insurmountable and can be resolved by imposing mutual fiduciary obligations on controlling and non-controlling shareholders. Fiduciary duty is a substitute for control, although imperfect in that the former requires judicial enforcement while the latter is self-executing. ${ }^{243}$ As a surrogate for control, it is not only a duty of the majority, but a right of the minority, just as control itself is a right of the majority. The fiduciary right departs, however, from corporate control in one significant respect-it is unpredictable. Minority shareholders always know who is in control of a close corporation, while the enforcement of fiduciary duty is in the hands of an unknown judge. The minority shareholder who is armed with this control surrogate can, at least in theory, "abuse" the majority with litigation or threats thereof. By burdening this fiduciary right with the same fiduciary

242 See Brudney, Fiduciary Ideology, supra note 1.

243 Hetherington and Dooley doubt the efficacy of legal principles requiring significant time and money costs for their enforcement. See Hetherington \& Dooley, supra note 10 , at $6,34,35,39$. Again, I suggest that this view is engendered by their focus on the remedial rather than the prophylactic function of the law. 
duty with which the right of corporate control is burdened, we can require both the majority and the minority to remain mindful of the interests of the other in exercising their rights and restore fiduciary duty to its prophylactic function.

In a sense, this proposal has been recognized implicitly by one court. In In re Kemp E E Beatley, Inc., ${ }^{244}$ the New York Court of Appeals, interpreting that state's oppression statute, noted that the statutory remedy was meant only to protect the minority, not to provide a weapon to enable it to obtain unfair advantage against the majority:

It would be contrary to this remedial purpose to permit its use by minority shareholders as merely a coercive tool. Therefore, the minority shareholder whose own acts, made in bad faith and undertaken with a view toward forcing an involuntary dissolution, give rise to the complained-of oppression should be given no quarter in the statutory protection. ${ }^{245}$

Thus, the protection of the rnajority's legitimate exercise of its "right of selfish ownership" is balanced with the need to protect the minority from wrongful deprivation by ensuring that the minority exercise its right to protection with the same sort of fiduciary restraint expected of the majority. Development of such a principle recognizes the need for shareholders to get along in a corporate relationship, as well as the social desirability of their doing so. It avoids the risk, recognized by the Wilkes court, that the cure itself may produce harm, and it encourages shareholders to recognize and respect each other's rights in a way that fulfills the prophylactic purpose of fiduciary duties, and hopefully keeps such disputes out of court.

Although this mutual altruism may seem too precious to some, and too reminiscent of Alfonse and Gaston to others, requiring both the controlling and minority participants to look out for the interests of the other restores a vision of human behavior and social good that is at the heart of fiduciary duty, while at the same time acknowledging the economic rights of each side. In so doing, it again elevates the desirable level of corporate ethics above the morals of the marketplace reflected in the current intent-based tests developed by courts. As a prophylactic measure, it is designed to avoid conflicts rather than to remedy them.

Any evaluation of the various approaches to fiduciary duty in close corporations must recognize their underlying philosophies as

24464 N.Y.2d 63, 473 N.E.2d 1173,484 N.Y.S.2d 799 (1984).

245 Id. at 74,473 N.E.2d at 1130,484 N.Y.S.2d at 806 (citations omitted). 
the principal guide to determining their desirability. Before we depart from the high social vision implicit in traditional notions of fiduciary duty in favor of easier and more expedient modes of analysis, we must ask whether the gain is worth the loss. 
